\title{
Fighting the Big War with the Small Hammer: Operational Planning for the Medium Force
}

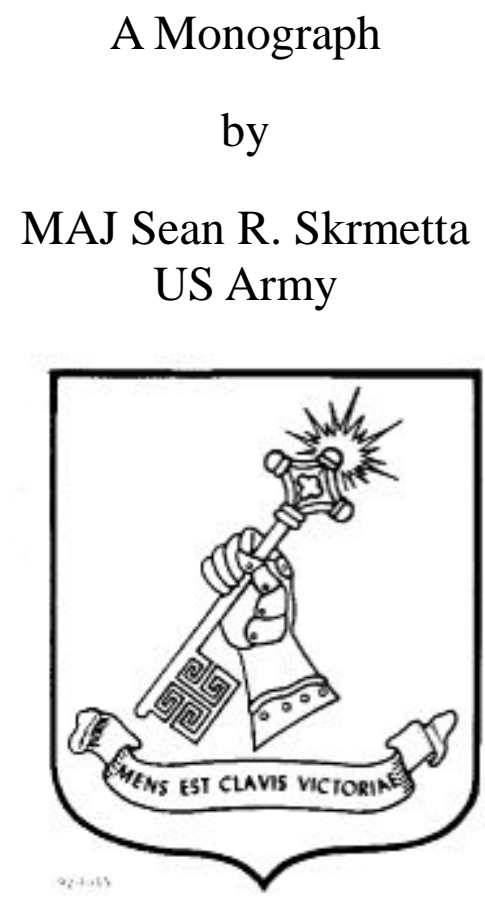

School of Advanced Military Studies

United States Army Command and General Staff College

Fort Leavenworth, Kansas

2015 


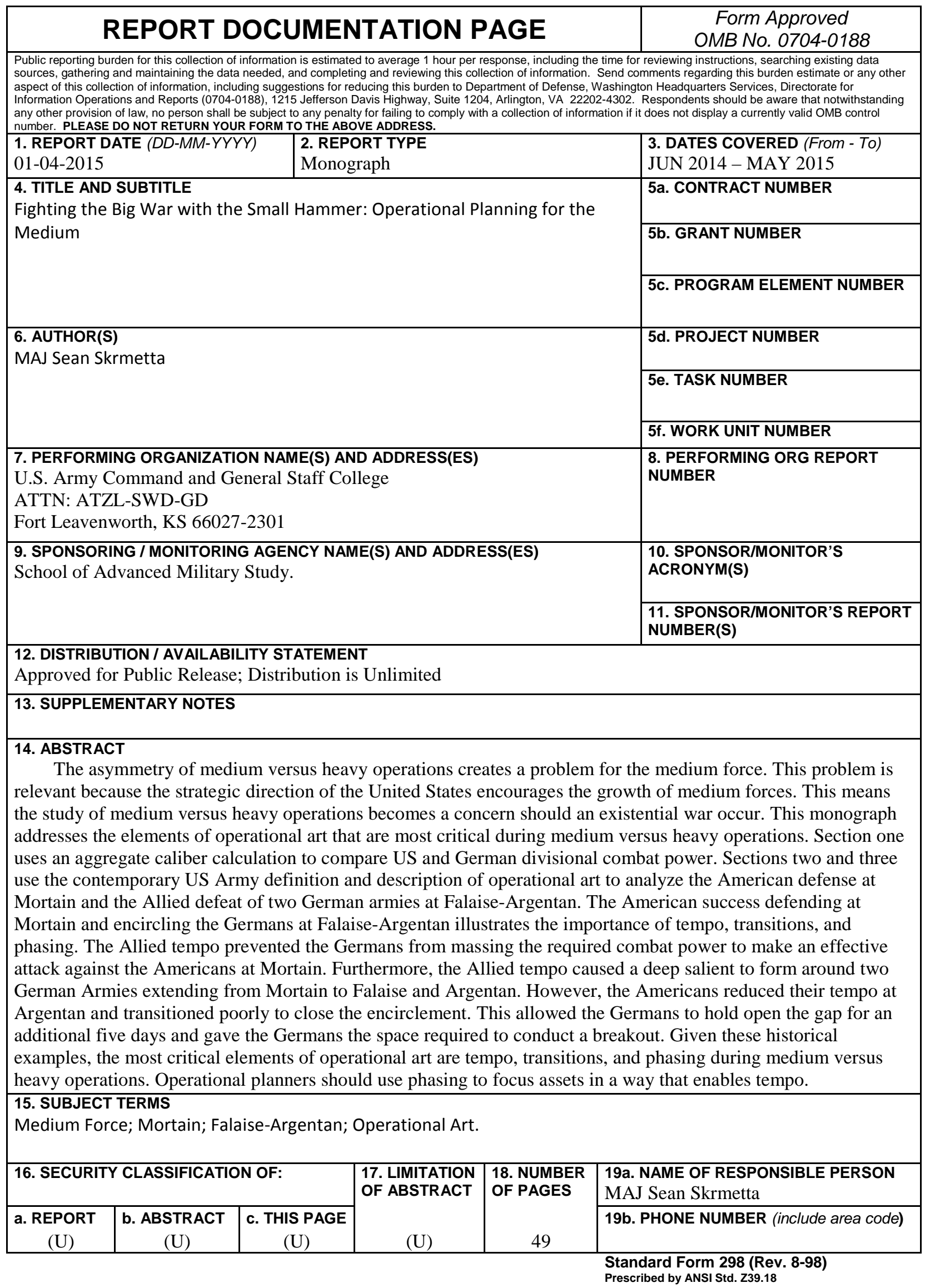




\section{Monograph Approval Page}

Name of

Candidate:

Monograph Title: $\quad$ Fighting the Big War with the Small Hammer: Operational Planning for the Medium Force

Approved by:

Peter J. Schifferle, PhD , Monograph Director

David P. McHenry, COL , Seminar Leader

Henry A. Arnold III, COL, IN

, Director, School of Advanced Military Studies

Accepted this $23^{\text {rd }}$ day of May 2015 by:

Robert F. Baumann, PhD

, Director, Graduate Degree Programs

The opinions and conclusions expressed herein are those of the student author and do not necessarily represent the views of the U.S. Army Command and General Staff College or any other government agency.(References to this study should include the foregoing statement.) 


\begin{abstract}
Fighting the Big War with the Small Hammer: Operational Planning for the Medium Force at the School of Advanced Military Studies, by Sean Skrmetta, 49 pages.

The asymmetry of medium versus heavy operations creates a problem for the medium force. This problem is relevant because the strategic direction of the United States encourages the growth of medium forces. This means the study of medium versus heavy operations becomes a concern should a existential war occur. This monograph addresses the elements of operational art that are most critical during medium versus heavy operations. Section one uses an aggregate caliber calculation to compare US and German divisional combat power. Sections two and three use the contemporary US Army definition and description of operational art to analyze the American defense at Mortain and the Allied defeat of two German armies at Falaise-Argentan. The American success defending at Mortain and encircling the Germans at Falaise-Argentan illustrates the importance of tempo, transitions, and phasing. The Allied tempo all along the Normandy Front prevented the Germans from massing the required combat power to make an effective attack against the Americans at Mortain. Furthermore, the Allied tempo caused a deep salient to form around two German Armies extending from Mortain to Falaise and Argentan. However, the Americans reduced their tempo at Argentan and transitioned poorly to close the encirclement. This allowed the Germans to hold open the gap for an additional five days and gave the Germans the space required to conduct a breakout. Given these historical examples, the most critical elements of operational art are tempo, transitions, and phasing during medium versus heavy operations. Operational planners should use phasing to focus assets in a away that enables tempo.
\end{abstract}




\section{Contents}

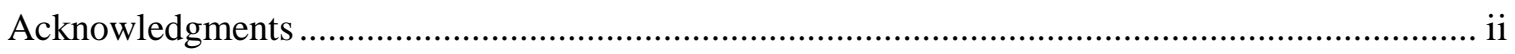

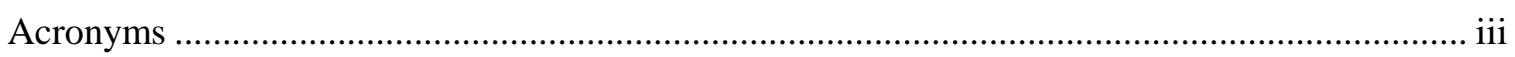

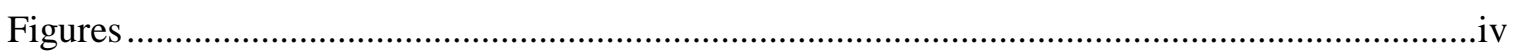

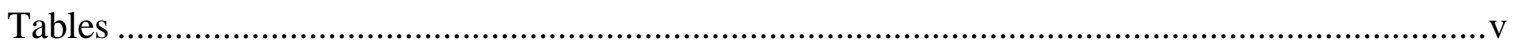

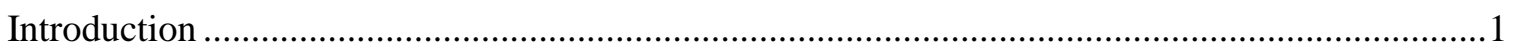

Section One: The Case for Medium in World War II ...............................................................

The Search for a Functional Definition of Medium Forces ....................................................... 8

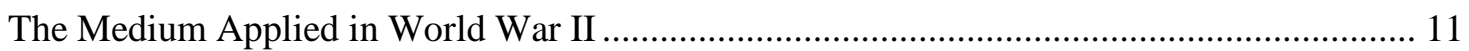

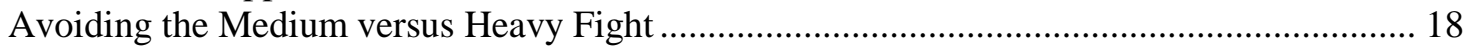

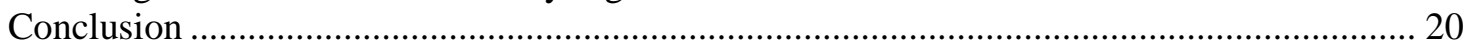

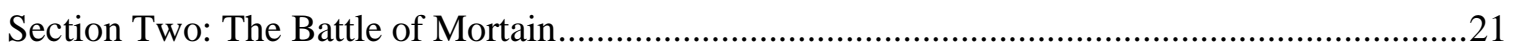

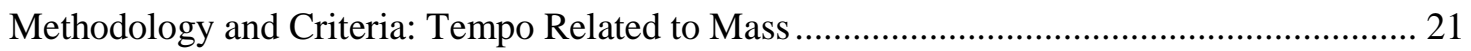

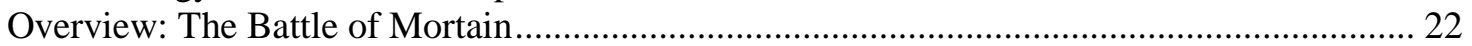

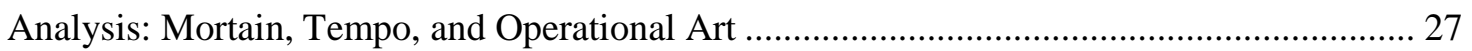

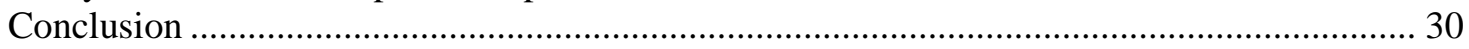

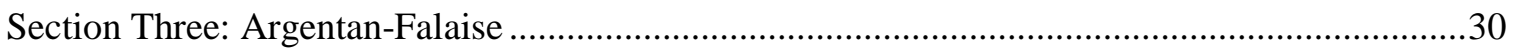

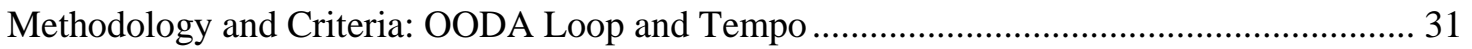

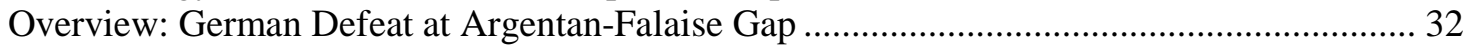

Analysis: Argentan-Falaise, Tempo, and Operational Art................................................. 36

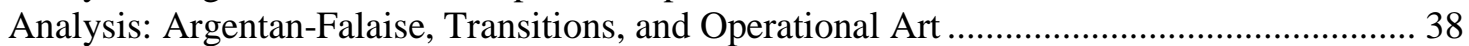

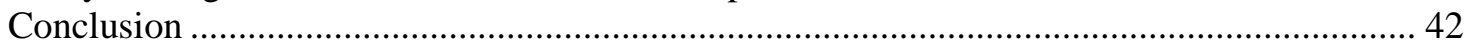

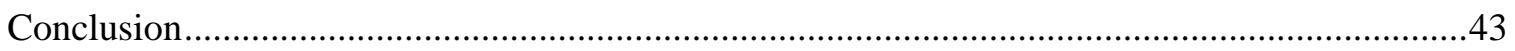

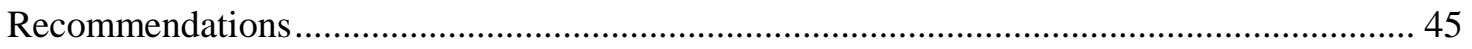

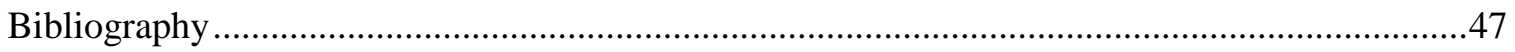




\section{Acknowledgments}

Thank you to my wife Katie whom is the inspiration for all that I do. In addition, I would like to thank COL David McHenry for his patience and coaching. He never hesitated to help me. Dallen Arny kept me motivated to challenge my body even when my mind was tired. Thank you, Dallen. Thank you to LTC Tom Felty. He showed me what it means to be a mentor. My fellow student, Oberstleutnant i.G. Kim Frerichs spend several hours with me translating German text to english. His efforts assisted me very much. I could not have written this monograph without Rusty Rafferty’s assistance. His research library skills are second to none. Finally, Dr. Pete Schifferle’s patience brought me through the monograph writing process. Moreover, the excellence of this former armor officer inspires me to uphold similar excellence in my generation. 


\section{Acronyms}

$\begin{array}{ll}\text { ADP } & \text { Army Doctrinal Publication } \\ \text { ADRP } & \text { Army Doctrinal Reference Publication } \\ \text { AT } & \text { Anti-Tank } \\ \text { Div } & \text { Division } \\ \text { HOW } & \text { Howitzer } \\ \text { HVY } & \text { Heavy } \\ \text { LT } & \text { Light } \\ \text { OODA } & \text { Observe, Orient, Decide, Detect } \\ \text { SP } & \text { Self Propelled } \\ \text { TD } & \text { Tank Destroyer } \\ \text { TK } & \text { Tank } \\ \text { TOE } & \text { Table of Organization and Equipment }\end{array}$




\section{Figures}

Figure 1. German Counterattack at Mortain............................................................................25

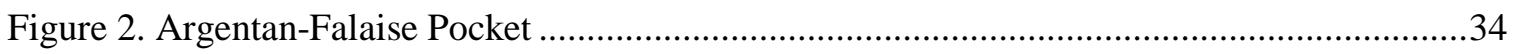

Figure 3. German Assembly Areas for the Argentan-Falaise Breakout......................................41 


\section{Tables}

Table 1. Aggregate Caliber of 1944 Panzer and Armor Division ................................................14

Table 2. Aggregate Caliber of 1st SS Panzer and 30th Infantry Division by 1944 Standard.........16

Table 3. Aggregate Caliber of 1st SS Panzer and 30th Infantry Division on August 7, 1944 .......17 


\section{Introduction}

In December 1944, I Company, 23rd Infantry Regiment defended east of Elensborn, Belgium against a German attack in the opening blows of the Battle of the Bulge. I Company stood against seven German infantry assaults that day. Then it happened. Five Tiger tanks appeared and lumbered toward I Company’s position with infantry support. Captain Charles MacDonald, I Company’s Commander, requested a Sherman tank platoon to intervene against the enemy armor. While waiting for an answer, he tried to stop the Tigers with artillery, but without a direct hit, the Tigers kept coming. The Tigers poured round after round of $88 \mathrm{~mm}$ destruction on I Company. MacDonald’s Battalion Commander responded that the Sherman tank platoon refused to close with the Tigers, because it was suicide for the lightly armored tanks. The Battalion Commander agreed with their judgement. Neither I Company nor the 23rd Regiment possessed a way to stop the Tigers. MacDonald’s defense folded. ${ }^{1}$

I Company’s situation illustrates a true tactical problem for the World War II American Army. The 23rd Regiment's tanks viewed attacking Tigers as suicide, because the Sherman's main gun lacked the capability to penetrate the enemy's armor. The Sherman main gun penetrated 75 millimeters of armor at 500 meters, whereas the Panther and Tigers boasted 120 millimeters and 100 millimeters of armor, respectively. The asymmetry in capabilities stems from the American use of a medium tank to fight a German heavy tank. ${ }^{2}$ Although 23rd Infantry’s tank on

${ }^{1}$ Charles MacDonald, Company Commander (New York, NY: Bantum Books, 1947), 126-128 and 148-149.

${ }^{2}$ David E. Johnson, Adam Grissom, and Olga Oliker, In the Middle of the Fight: An Assessment of Medium-Armor Forces in Past Military Operations (Santa Monica, CA: Rand Corporation, 2008), 27-28. 
tank fight created a tactical problem, this discussion explores how operational planning can mitigate shortcomings in tactical capability.

The problem of a medium force in a heavy fight is relevant in the contemporary environment for three reasons. First, the US Army’s strategic direction indicated a continued trend toward rapidly deployable forces. The 2014 Army Posture statement described the need for rapidly responsive expeditionary forces and discusses the continued development of the medium weight Stryker Combat Vehicle. ${ }^{3}$ The 2014 Quadrennial Defense Review states that projecting power represents a pillar of the Department of Defense Strategy. ${ }^{4}$ Section one of this monograph further discusses that the medium force's contribution to the strategic requirement to project power rapidly. ${ }^{5}$ Second, the US Army maintained zero medium capabilities in 1999. Since then, the number of medium weight Stryker brigades has steadily increased. ${ }^{6}$ Therefore, Stryker brigades make up an increasingly significant percentage of the force and would be included in any major conflict against an adversary capable of employing heavy armor. Although the Army would avoid pitting a medium force against a heavy force, the enemy would likely seek such engagements. ${ }^{7}$ Third, budget constraints make the medium force more attractive, because

${ }^{3}$ A Statement of the Posture on the Posture of the United States Army 2014 (Washington, DC: Department of Defense, 2014), 2 and 16. 12.

${ }^{4}$ Quadrennial Defense Review 2014 (Washington, DC: Department of Defense, 2014), document.

${ }^{5}$ The specifics requirements of rapid deployment remain outside the scope of this

${ }^{6}$ Mark J. Reardon and Jeffery A. Charleston, From Transformation to Combat: the First Stryker Brigade at War (Washington, DC: Center of Military History, 2007), 5-6; Alan Vick et al., The Stryker Brigade Combat Team: Rethinking Strategic Responsiveness and Assessing Deployment Options (Santa Monica, CA: Rand Corporation, 2002), 19; Stuart E. Johnson et al., "A Review of the Army's Modular Force Structure” (Santa Monica, CA: Rand Corporation, 2011), 19; Congressional Budget Office Study: An Analysis of the Army's Transformation Programs and Possible Alternatives (Washington, DC: Congressional Budget Office, 2009), 6.

${ }^{7}$ Section one's analysis justifies this statement. 
medium forces cost less to build and train compared to heavier forces. ${ }^{8}$ The medium forces will continue to make up a significant part of the US Army force structure based on these trends. Should major war occur with an enemy capable of using heavy armor in the coming decades, the medium force needs to maintain the ability to defeat a heavier force.

The relevance of medium armor in a heavy fight begs the question, what elements of operational art are most critical when fighting a heavy force with a medium force? This question requires several clarifying definitions. These definitions include operational art, the elements of operational art, and medium force. This monograph uses operational art as described in Army Doctrinal Publication (ADP) 3-0, Unified Land Operations, which is the capstone of Army Doctrine, and its subordinate document, Army Doctrinal Reference Publication (ADRP) 3-0, Unified Land Operations. ${ }^{9}$ First, ADP 3-0 defines Operational Art as "the pursuit of strategic objectives through the arrangement of tactical actions in time, space, or purpose." ${ }^{10}$ Second, ADRP 3-0 explains that the elements of operational art help conceptual understanding of the environment, visualization of an operational approach, and a description of that operational approach. According to ADRP 3-0, the elements of operational art are end state and conditions, centers of gravity, decisive points, lines of operation, lines of effort, operational reach, basing, tempo, phasing and transitions, culmination, and risk. ${ }^{11}$ Third, army doctrine fails to define a

${ }^{8}$ Stanley A. Horowitz, Robert J. Atwell, and Shaun K. McGee, Analyzing the Cost of Army Alternative Active/Reserve Forces Mixes (Alexandria, VA: Institute of Defense analysis, 2012), Appendix D.

${ }^{9}$ U.S. Army Doctrinal Publication (ADP) 3-0, Unified Land Operations (Washington, DC: Government Printing Office, 2011), ii; U.S. Army Doctrinal Reference Publication (ADRP) 3-0, Unified Land Operations (Washington, DC: Government Printing Office, 2012), iii; Army doctrinal manuals are arranged into a hierarchy. ADPs contain broad encompassing tenants of doctrine. ADRPs are subordinate to ADPs and provide more details to the broader ideas within the ADP.

${ }^{10}$ ADP 3-0, 9.

${ }^{11}$ ADRP 3-0, 4-2 and 4-3. 
medium force. ${ }^{12}$ The word medium implies an entity between two other entities. This definition relies on comparison to something else. ${ }^{13}$ However, in order to better define the scope of this discussion, this monograph describes the medium force as any force, which reduces its capabilities to increases its operational and/or strategic reach. Section one provides further discussion of this definition.

Historical examples provide the vehicle to examine medium versus heavy operations. ${ }^{14}$ The purpose of this examination is to inform modern operational planners. To that end, it excludes two major areas of discussion. First, the focus on medium versus heavy operations excludes irregular, low intensity, guerrilla, and insurgency warfare, because these types or approaches to war historically exclude a heavy force to oppose the medium force. ${ }^{15}$ Second, material solutions, organizational modifications, or national strategy represent issues above the operational planners control and, therefore, outside the bounds of an operational planner concerns.

With that goal in mind, historical examination shows that transitions, phasing, and tempo represent the most critical elements of operational art when employing a medium force against a heavy force. These three concepts come from ADRP 3-0. ADRP 3-0 includes transitions and phasing as one interconnected element. ${ }^{16}$ "Transitions mark a change of focus between the

${ }^{12}$ The US Army does classify specific equipment, notably helicopters and artillery pieces, in terms of weight, however these definition do not correlate to larger organizations as a whole.

${ }^{13}$ Oxford English Dictionary (New York, NY: Oxford University Press, 1980), 413.

${ }^{14}$ For simplicity, it uses the term medium versus heavy operations to describe the use of medium forces to fight heavy forces.

15 Johnson, Grissom, and Oliker, 12-13.

${ }^{16}$ Joint Publication (JP) 3-0 includes phasing and tempo in the elements of operational design. JP 3-0's discussion of anticipation bears many similarities to ADRP 3-0's description of transition and phasing. 
ongoing operation and execution of a branch or sequel" according to ADRP 3-0. Phasing describes a conceptual tool used to plan and manage transitions. Tempo describes the "relative speed and rhythm of military operations over time with respect to the enemy." ${ }^{17}$ This argument uses three major conclusions to prove this thesis.

First, the allied experience in World War II provides valuable insight for the study of medium versus heavy operations. In order to analyze medium versus heavy operations, section one defines medium forces by describing the compromise between operational and strategic reach with tactical firepower and protection. The World War II clash between American and German armor is a clash of medium and heavy tanks. This argument shows that German Panzer division maintained a firepower advantage over its American counterparts; however, the Americans allocated additional combat power, including field artillery, to mitigate their shortcoming. The story of the US Army Tank Destroyer refutes the notion that the Army will not use a medium force to fight a heavy force. US Army tank destroyers achieved many success, however these success were won by deviating from the doctrine of the day. ${ }^{18}$ This implies that regardless of the wishes of doctrine, the enemy may seek to engage our medium force with their heavy force. Section one sets the stage for section two's discussion medium versus heavy operation in World War II.

Second, the American defeat of the German offensive at Mortain proves that tempo is critical to medium versus heavy operations. In August 1944, the German Seventh Army launched an offensive to close the rupture created by the American breakout from the bocage. This German offensive used four panzer divisions to attack from east to west near the town of Mortain. The

${ }^{17}$ ADRP 3-0, 4-7 and 4-8.

${ }^{18}$ Johnson, Grissom, and Oliker, 36; For mor information regarding Tank Destoryer doctrine and execution see Section 1: Avoiding the Medium versus Heavy Fight. 
attack failed. ${ }^{19}$ American tempo all along the western front prevented the Germans from massing the requisite combat power for the operation. Section two shows that the relentless tempo of the Americans prevented the German offensive from gaining traction.

Third, the Allied encirclement of two German field Armies at Argentan-Falaise further proves the critical nature of tempo and highlights the importance of phasing and transitions. The German Mortain Offensive created a salient in which the allies surrounded two German field armies. The Allies intended to close the gap between Falaise and Argentan. However, the Americans hesitated at Argentan allowing the Germans time to re-orient and hold open the gap for five days. The Allies eventually surrounded and finished the two German armies in the pocket. ${ }^{20}$ This case reinforces the advantage that tempo provides the medium force. Further, the American hesitation in closing the Argentan-Falaise gap illustrates the critical nature of transitions during medium versus heavy operations. Tempo, phasing, and transition played a critical role during Falaise-Argentan encirclement.

The dilemma created by I Company, 23rd Regiment inability to stop the enemy Tiger tanks illustrates the problem of medium versus heavy operations. The problem becomes more

19 "VII Corps AAR 1-13 AUG," in Battle Analysis: Cobra Mortain Siegfried, Volume 3, Part 2 (Washington, DC: Government Printing Office, 1944), 136; Heinrich Eberbrach, Report of the Fighting of Panzergruppe West (Fifth Pz Army) from July 3-9 August 1944, Translation, Available at the Ike Skelton Combined Arms Library, Fort Leavenworth, KS, MS\# B-840; German Seventh Army, “War Diary”, Volume 4, 16 July 1944 to 16 August 1944, Translation, Available at the Ike Skelton Combined Arms Library, N-9821-C, 7; L. R. Adair et al., "Mortain: Defensive, Deliberate Defense, 30th Infantry, 9-13 August 1944,” (For Leavenworth, KS: Combat Studies Institute, 1983), 3-5.

${ }^{20}$ Martin Blumenson, U.S. Army in World War II, The Europe Theater of Operations: Breakout and Pursuit (Washington, DC: Government Printing Office, 1961), Map 17 and 556558; Carlo D’Este, Decision at Normandy (New York, NY: Dutton Incorporated, 1983), 432; Rudolf Gersdoroff, The Campaign for North France, Volume IV, Chapter 4, Translation by C. Lorsa, Available at the Ike Skelton Combined Arms Research Library, Fort Leavenworth, KS, N17500.55-D.2, 63; Robert Miller, August 1944 (Navato, CA: Persidio, 1988), 95-97; Canadian Participation in the Operations in North-West Europe, 1944, Report 64. Part III (Ottawa, Canada: Directorate of History, 1953), 5. 
relevant as the US Army adds medium weight Stryker Brigades to its force. How does a medium force overcome its disadvantages at the operational level using the elements of operational art as a theoretical basis? This discussion explores this question from the historical perspective to inform operational planning using a medium force. Allied operations during World War II provide a situation for this study. The American success blunting the German attack at Mortain teaches the importance of tempo in medium versus heavy operations. The American encirclement of the two German field armies at Argentan-Falaise further supports the critical nature of tempo, while highlighting the importance of transitions and phasing. History shows transitions, phasing, and tempo are among the most critical elements of operational art in medium versus heavy operations.

\section{Section One: The Case for Medium in World War II}

How does World War II inform modern operational art using the medium force? Section one frames World War II using medium versus heavy terms. Before describing World War II divisional organizations, this section explores a functional definition of the medium forces. The medium force stems from the compromise of firepower and protection to increase operational or strategic reach. Next, the comparison of American and German divisions provide context to analyze medium versus heavy operations. World War II German panzer divisions maintain a firepower advantage over American infantry and armor divisions, but the Americans used superior allocation of resources to make up for their short comings. Finally, the doctrine and application of the tank destroyer during this period explains that terrain and the enemy trumps doctrine. Ideally, an operational planner employs the medium force when it maintains a firepower advantage, but the examination of tank destroyer doctrine and execution during World War II suggests that the enemy and terrain might deny this possibility. The allied experience in North West Europe provides an excellent situation to study medium versus heavy operations. 
The Search for a Functional Definition of Medium Forces

What is a Medium Force? The definition for a medium force is important to describing medium versus heavy operations. The dictionary defines medium in relation to other entities. This is problematic because it allows a force to be medium in one context and heavy in another.

Therefore, this discussion seeks a more exact definition. The US Army defines its brigades by the primary combat system within the brigade. The size of armament and amount of protection on a combat system directly effects the weight of a combat system. However, increased weight means decreased operational and strategic reach due to logistic requirements, lift aircraft and bridging weight restraint. Therefore, medium forces facilitate operational or strategic reach by reducing armament and protection to decrease weight. ${ }^{21}$

The simple definition of medium forces are those that weigh more than light forces and less then heavy forces, but this definition creates a situation in which a force can meet the criteria for light, medium, and heavy at the same time. The US Army does not define a medium force directly. According to the Oxford American Dictionary, medium means the "middle quality or degree of intensiveness.”22 This implies that medium forces reference other entities to define its weight.

In 2008, David Johnson, Adam Grissom, and Olga Oliker’s conducted a Rand study regarding the effectiveness of medium forces. This study defined medium forces in two ways. The first definition uses the term medium in the context of the total force of the Army. The second definition describes medium in reference to the adversary weight. ${ }^{23}$ Both definitions define medium using relational terms in accordance with the dictionary definition.

${ }^{21}$ The physical size of equipment also effects operational and strategic reach, however the specifics requirements to facilitate reach remain outside the scope of this monograph.

${ }^{22}$ Oxford English Dictionary, 413.

${ }^{23}$ Johnson, Grissom, and Oliker, 9-10; The definition of Medium cannot be found in current editions of ADRP 3-0, ADRP 5-0, FM3-90.6, FM 3-21.21, or FM 3-90. 
The dictionary and Rand definitions become a problem, because a force might measure as heavy by its nation's standards and medium in comparison to its enemy. Further, technological advancement cause what was heavy yesterday to become medium today. The inconsistency of definition makes it valuable to search for a functional definition of medium instead of a comparative one.

Ground forces define themselves by the primary element expected to close with the enemy. ${ }^{24}$ For example, the US Army designates its heavy formation armored, because it expects the mechanized forces to close with the enemy and engage in the direct fight. Likewise, the US Army designates its light formations as infantry, because it expects foot soldiers to directly engage the enemy. ${ }^{25} \mathrm{~A}$ formation stripped of its heavy tanks and given medium vehicles would not logically retain the designation of a heavy formation. Furthermore, logistical and fire support elements represent enablers to the primary capability of the unit. These enablers must logically fit within the weight restriction of the element they support, because they are required to move with supported unit. Therefore, the weight of an organization derives from the capability provided by the primary combat vehicle that the force uses to close with the enemy.

The weight of a combat vehicle directly correlates to its capability in terms of survivability and firepower. In part, survivability derives from armor. Thicker armor equates to better survivability, but increases overall weight. The same logic applies to armament. Larger cannons provide more firepower at the expense of weight. Not only does a larger gun's weight

${ }^{24}$ Field Artillery and aviation provide significant combat power, but they are not expected to engage directly with the enemy to take and hold ground. They provide destructive support to allow other elements like infantry or armor to take and hold specific terrain.

${ }^{25}$ Field Manual (FM) 3-90.6, Brigade Combat Team (Washington, DC: Government Printing Press, 2010), 1-8 to 1-15: FM3-90.6 describes the organization for US Army Brigade Combat Teams. 
increase the overall weight of the vehicle, but a larger gun also requires more weight to absorb the recoil. This increased weight comes at a cost.

Weight maintains an inverse relation to operational and strategic reach. Weight inhibits operational and strategic reach in three ways. First, weight limits the types of bridges that a vehicle can cross. For example, the maximum capacity of highway and pontoon bridges restricted the weight of tank design during the period between World War I and World War II. ${ }^{26}$ Second, weight limits the number of vehicles an aircraft carries. For example, a C17 carries one Abrams Main Battle Tank. In contrast, a C17 can carry two Bradley Fighting Vehicles or four Stryker Infantry Carrier Vehicles. ${ }^{27}$ This means it requires twice the number sorties to lift a tank battalion to a theater of operations over a Bradley battalion and four times as many as a Stryker battalion. Third, heavier vehicles require more horsepower, which creates greater fuel consumption. For example, the M2 Bradley Fighting Vehicle weighs twenty tons and uses eighteen gallons of fuel an hour. In contrast, the M1 Abrams weighs seventy tons and requires fifty-six gallons an hour. ${ }^{28}$ The additional fuel requirement for the Abrams equates to thirty-two additional tons of fuel per day for a battalion. ${ }^{29}$ This translates into one additional C17 sortie per day per battalion. ${ }^{30}$

${ }^{26}$ Robert S. Cameron, Mobility, Shock, and Firepower: The Emergence of the U.S. Army's Armor Branch, 1917-1945 (Washington, DC: Center for Military History, 2008), 26.

${ }^{27}$ Christopher F. Foss, eds., Jane's: Armour and Artillery 2004-2005 (Alexandria, VA: Jane's Information Group, 2004), 159, 409, and 553; Paul Jackson et al., eds., Jane's: All the World's Aircraft 2010-2011 (Alexandria, VA: Jane's Information Group, 2010), 703. This section uses the maximum payload of C17 and the combat weight of the Abrams, Bradley, and Stryker to determine the number of vehicles a C17 carries. The weight of the Stryker exclude additional role on Armor and assumes that it would be brought and installed by follow on units.

${ }^{28}$ Foss, 159 and 409; Student Text 4-1, Theater Sustainment Battle Book (Fort Leavenworth, KS: Command and General Staff College, 2014), 4-7.

${ }^{29}$ That calculation derives from a 36 vehicle battalion times 8 hours of operations times the number of gallons an hour times the weight of JP8.

${ }^{30}$ Jackson, 703; That calculation uses the maximum payload of a C17 divided by the total weight of the fuel requirement times two sorties a day to equal sixteen hours of operation. The calculation assumes under combat conditions that a C17 would use its maximum payload. The specifics requirement of fuel transportation by air remains outside the scope of this monograph. 
Medium forces weigh less than heavy forces to increase operational and strategic reach. The compromise of firepower and protection for reach creates the medium force. As described above, the heavier the vehicle the greater the firepower and protection. However, weight reduces reach. This idea defines medium forces. Medium forces are designed to facilitate operational or strategic reach through reduction in weight.

\section{The Medium Applied in World War II}

The German heavy Panzer Division outgunned their American medium counter parts, or did it? This section examines the correlation of weight, organization, and firepower for German and American divisions. The aggregate caliber calculation provides an imperfect, but simple measure to compare divisions with dissimilar equipment. By this calculation, the Panzer Division outgunned both an American armored and infantry division. However, the Americans allocated their resources to mitigate their shortcoming. On August 7, 1944, the aggregate caliber calculation shows that the American 30th Division received enough resources to outgun the opposing German Division by three to one. The calculation of aggregate caliber illustrates the superior organic firepower of a Panzer Division. However, the Americans mitigated their disadvantage by concentrating resources.

The aggregate caliber calculation provides a measure that accounts for both the organization and capability of a division. The comparison of equipment density in two different types of organizations fails to given accurate picture of how those organizations compare in total capability. This stems from the inherent difference in capability of each piece of equipment within an organization. For example, the 1944 Panzer Division organization maintains fewer tanks then its American counterpart, but these tanks retain better capability. In contrast, the 
American armor division maintained far fewer anti-tank guns than its German antagonist. ${ }^{31}$ The aggregate caliber calculation provides a metric to compare organizations with different capabilities.

This section calculates aggregate caliber in two steps. First, it multiplies the number of particular piece of equipment by the caliber of its armament to obtain a total caliber for the specific piece of equipment. Second, the calculation sums the aggregate calibers of the major pieces of equipment for the organization. ${ }^{32}$ This calculation has several shortcomings. It does not account for the different effects of ammunition. For example, it fails to account for the different effects of howitzer rounds versus anti-tank rounds or the variance of penetration of a high velocity gun versus a low velocity gun. Further, it fails to account for leadership, training, intelligence, or other aspects of military operations. However, it does provide a simple measure to compare firepower between two divisions.

In 1944, the aggregate caliber of German SS Panzer Division is greater than its American counterpart, as expected by its heavier nature. The US armor division maintained more than twice as many tanks as the SS Panzer division. However, the panzer division maintained more than four times as many anti-tank guns of all calibers. ${ }^{33}$ Table 1 shows the aggregate caliber of a Panzer division is 20\% more than the Armor Division. The Panzer Division’s aggregate caliber, density, and capability of equipment align it with the characteristic of a heavy force. However, section two's case study of Mortain analyzes the operations of an American Infantry Division against a SS Panzer Division.

${ }^{31}$ Johnson, Grissom, and Oliker, 27-28; Technical Manual (TM-E) 30-451, Handbook of German Forces (Washington, DC: War Department, 1945), II-10 and II-11; Table of Organization and Equipment (TOE) No. 17, Armor Division (Washington, DC: War Department, 1944), 2-5.

32 See table 1 for an example.

33 TM-E 30-451, II-10 and II-11; TOE No. 17, 2-5. 
Table 1. Aggregate Caliber of 1944 Panzer and Armor Division

\begin{tabular}{|c|c|c|c|c|c|c|}
\hline \multicolumn{7}{|c|}{ German Panzer Division } \\
\hline Equipment & Caliber & $\begin{array}{l}\text { Authorized } \\
\text { per Division }\end{array}$ & $\begin{array}{c}\text { Caliber by } \\
\text { System }\end{array}$ & & & \\
\hline Panzer IV & $75 \mathrm{~mm}$ & 64 & 4800 & & & \\
\hline Panther & $75 \mathrm{~mm}$ & 62 & 4650 & \multicolumn{3}{|c|}{ Total Authorized (German) } \\
\hline SP Heavy Howitzer & $150 \mathrm{~mm}$ & 24 & 3600 & Tanks & & 126 \\
\hline Heavy Howitzer & $150 \mathrm{~mm}$ & 12 & 1800 & Howitzers & $\boldsymbol{F}$ & 84 \\
\hline SP Howitzer & $105 \mathrm{~mm}$ & 12 & 1260 & AT Guns & & 263 \\
\hline Towed Howitzer & $105 \mathrm{~mm}$ & 12 & 1260 & \multicolumn{2}{|c|}{ Total } & 473 \\
\hline Light Howitzer & $75 \mathrm{~mm}$ & 24 & 1800 & & & \\
\hline AT Gun & $88 \mathrm{~mm}$ & 12 & 1056 & & & \\
\hline Super Long AT Gun & $75 \mathrm{~mm}$ & 62 & 4650 & & & \\
\hline Long AT Gun & $75 \mathrm{~mm}$ & 64 & 4800 & & & \\
\hline SP AT Gun & $75 \mathrm{~mm}$ & 69 & 5175 & & & \\
\hline AT Gun & $75 \mathrm{~mm}$ & 12 & 900 & & & \\
\hline Light AT Gun & $37 \mathrm{~mm}$ & 8 & 296 & & & \\
\hline Light AT Gun & $20 \mathrm{~mm}$ & 36 & 720 & & & \\
\hline & & Aggregate & 36767 & & & \\
\hline \multicolumn{7}{|c|}{ American Armor Division } \\
\hline Equipment & Caliber & $\begin{array}{l}\text { Authorized } \\
\text { per Division }\end{array}$ & $\begin{array}{c}\text { Caliber by } \\
\text { System }\end{array}$ & & & \\
\hline Sherman & $75 \mathrm{~mm}$ & 168 & 12600 & \multirow{2}{*}{\multicolumn{3}{|c|}{ Total Authorized (US) }} \\
\hline Sherman (HVY) & $75 \mathrm{~mm}$ & 18 & 1350 & & & \\
\hline Stuart (LT) & $37 \mathrm{~mm}$ & 83 & 3071 & Tanks & & 269 \\
\hline SP HOW (LT) & $75 \mathrm{~mm}$ & 17 & 1275 & Howitzers & 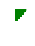 & 71 \\
\hline SP HOW HVY & $105 \mathrm{~mm}$ & 54 & 5670 & AT Guns & 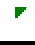 & 72 \\
\hline AT Gun SP & $76 \mathrm{~mm}$ & 36 & 2736 & \multirow{2}{*}{\multicolumn{2}{|c|}{ Total }} & 412 \\
\hline \multirow[t]{2}{*}{ AT Gun Towed } & $76 \mathrm{~mm}$ & 36 & 2736 & & & \\
\hline & & Aggregate & 29438 & & & \\
\hline
\end{tabular}

Source: Created by Author. ${ }^{34}$

${ }^{34}$ Steven J. Zaloga, US Tanks and Tank Destroyer Battalions in the ETO 1944-45, ed. Ducan Anderson, Marcus Cowper, and Nikolai Bogdanovic (Oxford, UK: Osprey Direct, 2005), 30, 35, and 39. This book provides data as to the numbers of specific models of tanks in 12th Army Group during 1944.; George Forty, German Tanks of World War Two 'In Action' (New York, NY: Sterling Publishing Co, 1987), 79 and 101: TOE No. 17, 1944, 2-5; TOE No. 17, 1942, 2-3; The 1944 Table of Organization and Equipment (TOE) No 17 does not include antitank guns. The calculation assumes augmentation by a tank and tank destroyer battalion.; R.P. Hunnicutt, Sherman: A History of the American Medium Tank (Novato, CA: Presidio Press, 1978), 545; Armin Halle, Tanks: An Illustrated History of Fighting Vehicles (Greenwich, CT: New York Graphic Society, 1971), 92, 103, and 105; TM-E 30-451, II-10 and II-11. This document provides equipment statistics for German Division. Table one uses the organization of a SS Panzer Division 
Section two describes the clash between 30th Infantry Division and 1st SS Panzer

Division starting on August 7, 1944. ${ }^{35}$ Using 1944 organizations, the aggregate caliber of the 30th Infantry Division in its standard form measure less than half of the 1st SS Panzer Division. A US Army infantry division did not maintain their own tanks formations. However, independent tank and tank destroyer battalions shared a habitual relationship with a division. Table 2 includes 743rd Tank Battalion and 823rd Tank Destroyed Battalion in the aggregate caliber calculation. ${ }^{36}$ Table 2 shows 30th Division maintained half the tanks and one-fifth the anti-tank guns of its antagonist. The 1st SS Panzer Division's aggregate caliber measure seems overwhelming, but this calculation does not reflect all the conditions present in World War II.

${ }^{35}$ Other US and German Division were involved in section two's description of August 7, 1944. The 30th Division received the majority of the blow from the German attack. The 1st SS was the strongest of the attacking divisions.

36 Table Of Organization and Equipment (TOE) No. 7, Infantry Division (Washington, DC: War Department, 1944), 2-5; Zaloga, 78-91; Adair et al., Chart E; "30th Division AAR August 44” in Battle Analysis: Cobra Mortain Siegfried, Volume 3 Part 2 (Washington, DC: Government Printing Press, 1944), 1. 
Table 2. Aggregate Caliber of 1st SS Panzer and 30th Infantry Division by 1944 Standard

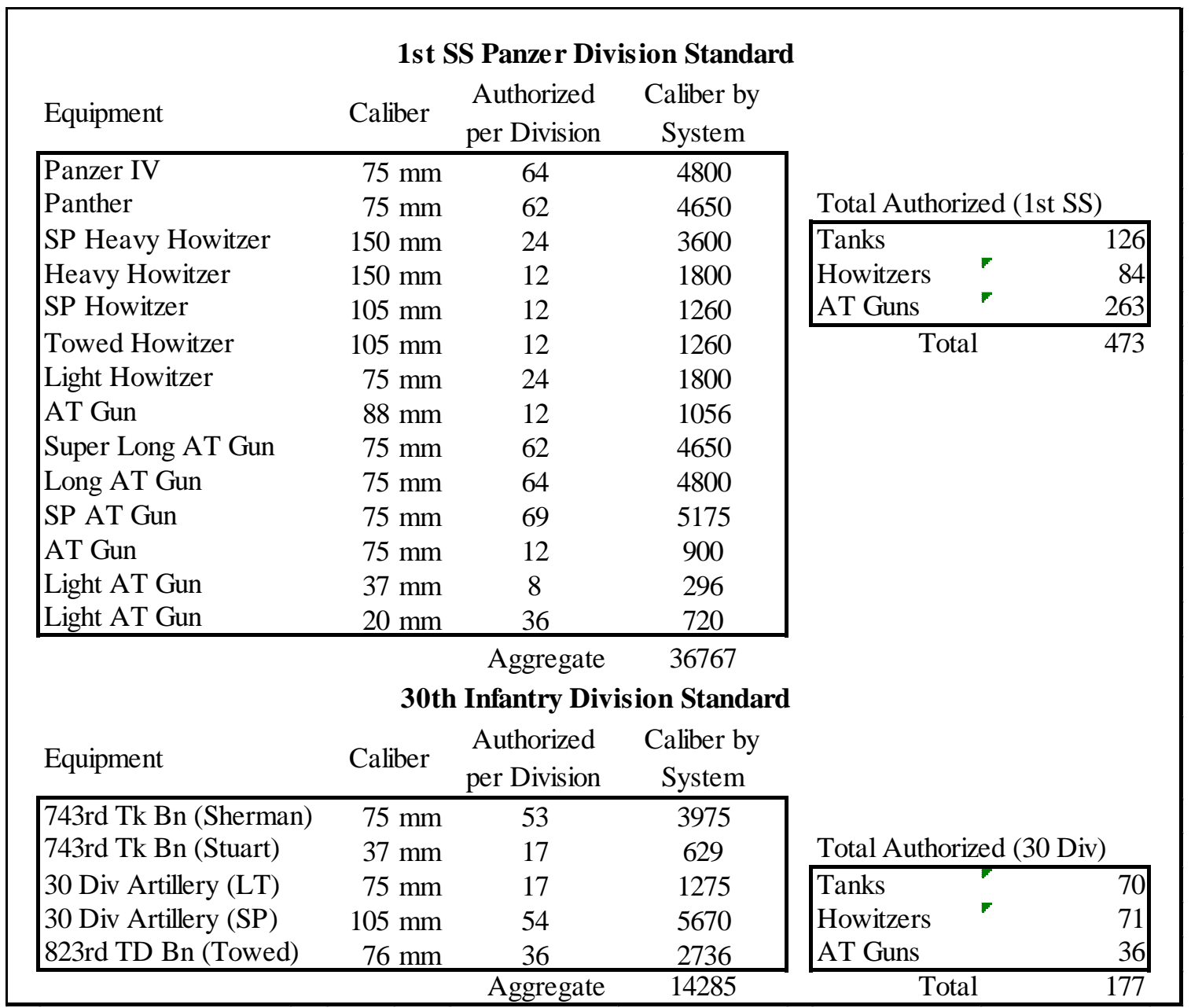

Source: Created by Author. ${ }^{37}$

The Americans mitigated their medium weight formation by pooling resource at critical points. Table 3 shows the aggregate caliber of 30th Division on August 7, 1944. August 7 marks the day the Seventh German Army initiated the attack that is the subject of section two's case study. On that day, 30th Division maintained its standard organization and it received support

${ }^{37}$ Zaloga, 23, 30, 35, and 39; Forty, 79 and 101; Hunnicutt, 545; Halle, 92, 103, and 105; TM-E 30-451, II-10 and II-11; Adair et al., Chart E. 
from seven additional field artillery battalions, the 33rd Tank Regiment, and the 629th Tank Destroyer Battalion. ${ }^{38}$ This gave the 30th Division a three to one advantage over 1st SS Panzer in terms of aggregate caliber. ${ }^{39}$

Table 3. Aggregate Caliber of 1st SS Panzer and 30th Infantry Division on August 7, 1944

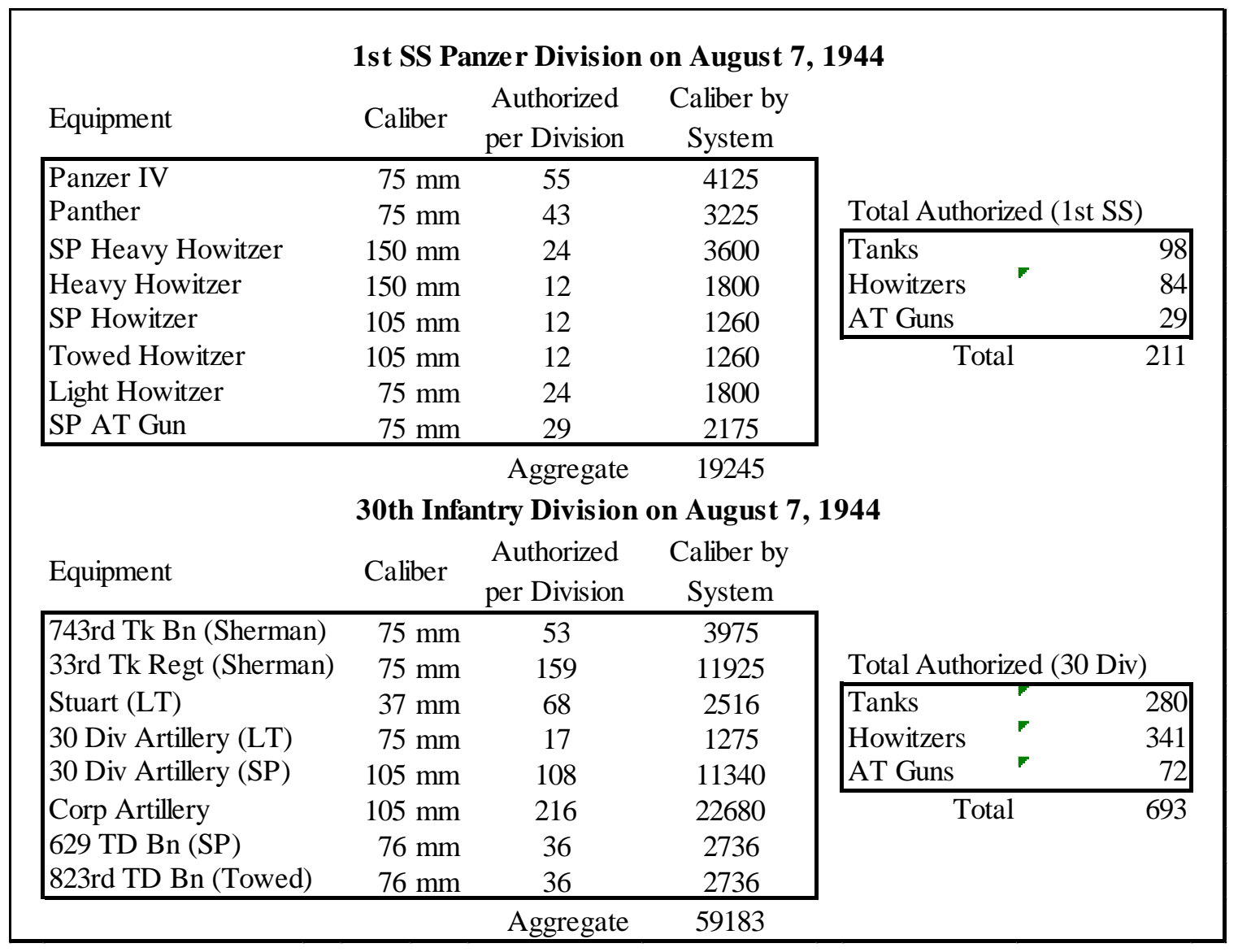

${ }^{38}$ Reardon, Victory at Mortain, 69 and 134; “30th AAR August 44,” 158-159.

39 The 1st SS Panzer Division was the strongest of the four divisions that attacked the 30th Division on August 7, 1944. This attack is the subject of section two. 
Source: Created by Author. ${ }^{40}$

American aggregate caliber on August 7, 1944 shows that the weight of an organization is not everything. The examination of aggregate caliber provides a metric to compare American and German divisions. The aggregate caliber provides a calculation of the total potential for firepower in a given organization. The Panzer Division maintained a superior aggregate caliber to the both the American armor and infantry division. The Americans mitigated this by pooling resources. For example on August 7, 1944, the American 30th Division maintained a three to one advantage over the 1st SS Panzer Division through attachments and III Corps artillery support. Although the Panzer Division represented a heavier force then its American counterpart, the Americans concentrated their resources to overcome this disadvantage.

Avoiding the Medium versus Heavy Fight

The comparison of the Sherman and Panther makes it clear that a medium on heavy fight creates a problem for the medium force. from a medium force perspective, the best option avoids such a battle all together. . However, the idea that doctrine alone dictates the impact of certain capabilities ignores the effects of the terrain and enemy on the situation. Tank destroyer doctrine pitted tank destroyers against enemy tanks to allow friendly tanks to concentrate on the enemy's logistics. ${ }^{41}$ According to Johnson, Grissom, and Oliker, tank destroyers fought according to

${ }^{40}$ Zaloga, 23, 30, 35, and 39; Forty, 79 and 101; Hunnicutt, 545; Halle, 92, 103, and 105; TM-E 30-451, II-10 and II-11; Adair et al., Chart E; Reardon, Victory at Mortain, 54, 69, and 134-135; Reardon describes the Artillery Support to the Battle at Mortain, 1st SS Panzer's vehicle strength and the commitment of 33rd Armor, CCB, 3rd Armor Division Regiment in support of of the 30th Infantry Division on August 7, 1944; "VII Corps AAR 1-13 AUG," 93; This document shows the attachment of CCB, 3rd Armor to 30th Division; "30th Div AAR AUG '44," 155; This document shows the attachment of 629 Tank Destroyer Battalion.

${ }^{41}$ Cameron, 408; Field Manuel (FM) 18-15, Tank Destroyer Field Manuel (Washington, DC: Government Printing Press, 1942), 1 and 7. 
doctrine on only one occasion during World War II—during the Battle of the Bulge. Prior to the Bulge, the French countryside and German doctrine nullified the guiding tenants of tank destroyer doctrine. ${ }^{42}$ The tank destroyer's experience in World War II illustrates that enemy and terrain effects the implementation of tactics to a greater degree than doctrine. This applies to medium versus heavy operations, because it suggests that the enemy and terrain may set conditions that require the medium force to engage with the heavy force out of necessity.

Prior to World War II, the tenants of tank destroyer doctrine centered reconnaissance, coordination, and mass. Doctrine dictated that tank destroyer units conduct reconnaissance and coordination with adjacent units to determine the location of enemy armor. Tank destroyers massed, ideally at the battalion level or higher, against the enemy tank formation once identified by the recon effort or an adjacent units. ${ }^{43}$ This action kept enemy tanks from disrupting friendly tank’s exploitation.

However, this doctrine ignored the effects of terrain and the enemy on operations. The doctrine failed to account for the Germans’ combined arms approach. Doctrine assumed that tank destroyers massed against enemy tanks, which allowed friendly tanks to focus on enemy infantry and logistics. The German refused to conform to US doctrine. Most tank battles were small. This prevented tank destroyers from massing against German tanks. Furthermore, complex terrain like the bocage and urban terrain lent itself to small unit action preventing mass armor formation. This complex terrain caused close range armor engagement where only a limited number of tanks or tank destroyers could employ However, the American tank destroyers achieved many successes despite the doctrine. For example, one tank destroyer platoon held off the weight of a German division attack at St. Bathelemy on August 7, 1944 during the Battle of Mortain. The platoon

\footnotetext{
42 Johnson, Grissom, and Oliker, 36.

${ }^{43}$ Cameron, 408-409 and 497; FM 18-15, 1, 7, and 20.
} 
from 823rd Tank Destroyer (TD) Battalion success was not born out of recon, coordination, or mass. In fact, the 823rd Tank Destroyer Battalion spread its guns in a thin line to protect the 30th Infantry Division front in conflict with doctrine. ${ }^{44}$ The effects of enemy and terrain nullified the intent of US tank destroyer doctrine, so the Americans found success by deviating from the doctrine.

The US Army tank destroyer presents a lesson about the balance of doctrine and the environment. During World War II, tank destroyer doctrine centered on massing anti-tank units to destroyer enemy tanks. German doctrine and French terrain nullified this concept. The Americans obtained success through using the tank destroyer units in ways that matched the environment. The tank destroyer's doctrinal flaw teaches that enemy and terrain create conditions where a medium force cannot be used as designed. Ideally, medium forces are limited to engagements in which the medium force maintains an advantage over the enemy. The enemy may have a different idea.

Conclusion

One look at the antiquated Sherman tank calls into question the usefulness of the modern study of medium versus heavy operation in World War II. Yet, World War II provides important insight into this type of operation. In order to precisely define the scope of medium versus heavy operations, section one developed a functional definition for medium based on the compromise of armament and protection for operational or strategic reach. Next, this section showed that the German Panzer Division out gunned American armor and infantry divisions. The Americans overcame this shortfall by concentrating resources to mitigate their lack of firepower using both field artillery and additional tanks support. Finally, the US Army tank destroyer illustrated that

${ }^{44}$ Cameron, 409 and 497; Johnson, Grissom, and Oliker, 35; Christopher R. Gabel, Seek, Strike, and Destroyer: U.S. Army Tank Destroyer Doctrine in World War II (Fort Leavenworth, KS: Combat Studies Institute, 1985), 56.; Reardon, Victory at Mortain, 85 and 123-126. 
the terrain and enemy take precedence over doctrine. This means that a medium force may be required to engage with a heavy force regardless of what the doctrine dictates.

\section{Section Two: The Battle of Mortain}

After D-Day and the subsequent break out from Normandy, the German Seventh Army launched a counter attack, Operation Luttich. Hitler intended this operation to stop the American onslaught, but it ended in a German defeat at the French town of Mortain. The American victory provides a case study to inform medium versus heavy operations. The analysis of Mortain uses the relationship of tempo and mass as methodology to understand the American victory at Mortain. The Battle of Mortain pitted the American 30th Infantry Division against four divisions of the Seventh German Army in August 1944. ${ }^{45}$ This case study shows that the Americans defeated the Germans through superior tempo, which prevented the Germans from massing the required combat power to mount an effective attack. The Battle of Mortain illustrates the critical nature of tempo during medium versus heavy operations.

Methodology and Criteria: Tempo Related to Mass

This section uses the criteria of the enemy's ability, or rather inability, to mass to prove that friendly tempo represents a critical element of operational art in the context of medium versus heavy operations. It uses current US Army Doctrine to facilitate conclusions that are relevant to contemporary operations. ${ }^{46}$ Army Doctrine Reference Publication (ADRP) 3-0 designates tempo as an element of operational art and defines it as "the relative speed and rhythm

45 Adair et al., 2-1 and 2-13; Mark J. Reardon, Victory at Mortain: Stopping Hitler's Panzer Counter Offensive (Lawrence, KS: University Press of Kansas, 2002), 54-55; German Seventh Army, "War Diary”, Volume 4, 7 and 12

${ }^{46}$ This study uses current doctrine instead of World War II doctrine to add relevence to current planning and for consistency. 
of military operations over time with respect to the enemy." ${ }^{47}$ ADRP 3-0 further states, "Ultimately, the goal is maintaining a tempo appropriate to retaining the initiative." 48

Furthermore, the appropriate tempo enables mass, because it facilitates synchronization. ADRP 30's discussion of tempo seems unrelated to the idea of mass. ADRP 3-0 highlights mass as a principle of joint operations and defines it as the ability to "concentrate the effects of combat power at the most advantageous place and time to produce decisive results." ${ }^{49}$ Further, Joint Publication 3-0 explains that, "in order to achieve mass ...capabilities are integrated and synchronized where they will have a decisive effect in a short period of time."50 Therefore, in order to mass, an entity must integrate and synchronize its capabilities. Friendly tempo seeks to retain initiative, which interrupts the enemy's ability to synchronize—denying mass. The relationship between friendly tempo and the interruption of enemy mass explains the allied defeat of Operation Luttich.

Overview: The Battle of Mortain

The battle at Mortain resulted from the clash US 30th Infantry Division (under VII Corps) and the German XLVII Panzer Corps (under Seventh German Army). In the summer of 1944, the Seventh German Army attacked to close the rift opened by the Allied break out of Normandy. The US 30th Infantry Division stopped the German attack near the town of Mortain.

\footnotetext{
${ }^{47}$ ADRP 3-0, 4-7.

${ }^{48}$ Ibid.

${ }^{49}$ ADRP 3-0, 4-2.

${ }^{50}$ Joint Publication (JP) 3-0, Joint Operations (Washington, DC: Government Printing
} Office, 2011), A2. 
The 30th Infanty Division counter attacked and pushed Seventh German Army East of Mortain. ${ }^{51}$ The battle at Mortain represents an example of how to defeat a heavy force with a medium force. In early August 1944, the Germans planned Operation Luttich to seize the coastal town of Avranches anchoring an east-west defensive line with the ocean and sealing the rupture made by Operation Cobra. Hitler saw establishing this line as the first step to collapsing the American beachhead at Normandy. Hitler intended the attack to include up to eight divisions under Seventh German Army, but Allied pressure prevented the massing of such a large force. ${ }^{52}$ For example, when Seventh German Army requested additional Panzer Divisions from II SS Panzer Corps, the Corps commander explained that the British offensive near Saint Lo created too much pressure to release any assets. ${ }^{53}$

The Seventh German Army planned to assemble 2nd SS Panzer Division, 2nd Panzer Division, 116th Panzer Division, and 1st SS Panzer Division under XLVIII Corps. The commander of Seventh German Army, Field Marshall Von Kluge intended for XLVIII Corps to attack with two echelons. The lead echelon consisted of three divisions and the second echelon followed with one division. The lead echelon included 116th Panzer Division, 2nd Panzer Division, and 2nd SS Panzer Division, which planned to attack along two axis apiece. The 1st SS Panzer was to trail the three lead divisions and exploit their success. ${ }^{54}$

On August 7, 1944, the German XLVII Corps launched a piece-meal attack against the American 30th Division. On the day before, 30th Infantry Division occupied a line from

${ }^{51}$ Adair et al., 1-1; German Seventh Army, "War Diary”, Volume 2, 16 July 1944 to 16 August 1944, Translations, Available at the Ike Skelton Combined Arms Library, N-9821-B, 5 AUG 1944.

52 Adair et al., 2-1 and 2-13; Blumenson, 459

${ }^{53}$ Mark J. Reardon, Victory at Mortain: Stopping Hitler's Panzer Counter Offensive (Lawrence, KS: University Press of Kansas, 2002), 51.

${ }^{54}$ L. R. Adair et al., 4-10; Blumenson, 460; Reardon, Victory at Mortain, 51. 
Cherence-Le-Roussell to Mortain. The German Panzer units arrived at their assembly areas late and disorganized due to American fighter-bomber activity and Allied attacks all along the front. For example, the XLVII Corps reported that the 1st SS Division arrived late and without its attachments tanks and artillery from the 116th Panzer Division. At approximately midnight on August 07, 1944, the German XLVII Corps initiated Operation Luttich. In the South, 2nd SS Panzer Division attacked on time along two avenues surrounding 2nd Battalion, 120th Infantry on hill 317 and pushing the remainder of the 120th Infantry Regiment out of Mortain. In the center, 1st SS Panzer Division attacked along two avenues against 117th Infantry Regiment, but only one of the two prongs attacked on time. The northern prong attacked without waiting for attachments from 116th Panzer Division, achieved surprise, and penetrated approximately six miles to Le Mesnil-Adelee. The southern prong attacked late to wait for attachments from 116th Panzer Division and seized Saint Barthelemy, but stopped short of Juvigny-le-Tertre, which controlled a key lateral road network. ${ }^{55}$ In the north, 116 th Panzer failed to obtain any success. ${ }^{56}$ The German failure to launch a coordinated attack foreshadowed the outcome of Operation Luttich.

${ }^{55}$ L. R. Adair et al., 3-5, and 4-11 to 4-12; Thirtieth Infantry Division G2, “After Action Report August 1st -31st 1944”, Available at the Ike Skelton Combined Arms Library, N12139; Reardon, Victory at Mortain, 92-94; German Seventh Army, "War Diary”, Volume 4, 4-7.

${ }^{56}$ German Seventh Army, “War Diary,” Volume 2, 7 AUG 1944. 


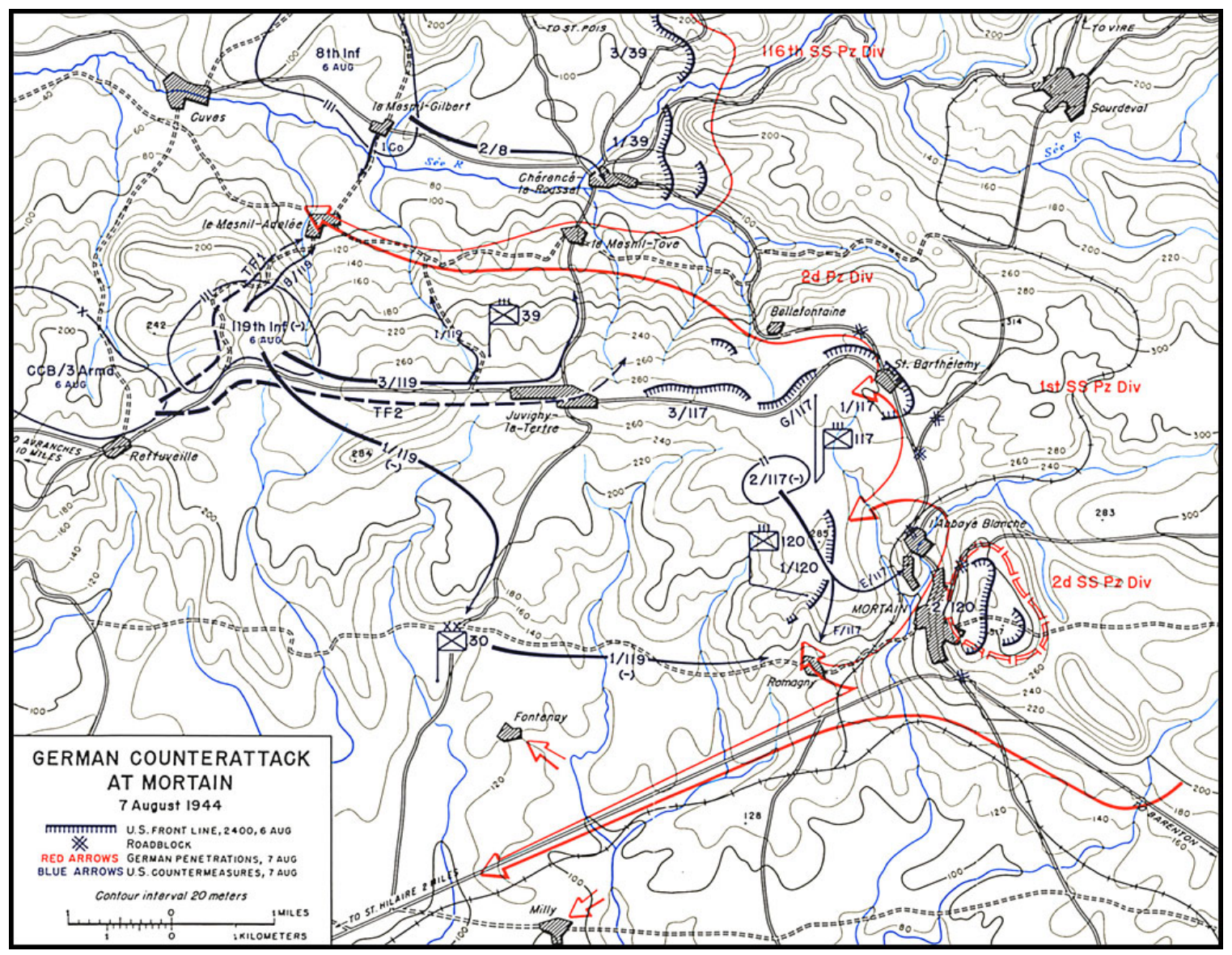

Figure 1. German Counterattack at Mortain

Source: Martin Blumenson, U.S. Army in World War II, The Europe Theater of Operations: Breakout and Pursuit (Washington, DC: Government Printing Office, 1961), Map X.

By the evening of August 8, the 30th Infantry Division caused the German attack to culminate well short of initial objectives. In the south, 2nd SS Division made a three kilometer penetration which seized Mortain but failed to take hill 317 from 2nd Battalion, 120 Infantry leaving a significant force on a dominate piece of terrain. In the center, the 117th Infantry held 2nd Panzer Division's southern penetration well short of Junivy, which exposing 2nd Panzer's flank along their six mile penetration to Le Mesnil Adelee. In the north, 39th Infantry Regiment 
continued to hold its position at Cherence-le-Roussel against 116th SS Panzer Division. ${ }^{57}$

Although the German offensive stopped, several hard days of fighting remained ahead before the Americans retook the offense.

On August 10, the 30th InfantryDivision's counter attack began to gain traction eventually pushing the Germans east of Mortain. By August 11, 119th Infantry Regiment controlled Mesnil-Tove, which caused the collapse 2nd Panzer Division’s northern penetration. The same day, 2nd SS Panzer Division withdrew from position west of Mortain, which removed XLVII Corps southern penetration. The US attack gained ground but lacked coordination to gain significant momentum. Regardless of Allied gains, Hitler ordered the attack to continue toward Avranches. However, the Canadian attack toward Falaise prevented von Kluge from repositioning the requisite combat power to resume the offense. On August 11, 1944, von Kluge met with his subordinate commanders and decided to withdraw based on the Canadian threat to the German supply area. ${ }^{58}$ The Seventh German Army withdrawal made space for the 120 th Infantry Regiment to regain contact with its “lost battalion” on hill 317 and reestablish its initial positions from Cherence-le-Roussel to Mortain. ${ }^{59}$ The 30th Infantry Division stymied the weight of the German offensive around Mortain and allied attacks created pressure in Normandy, which prevented the German freedom of maneuver and tied von Kluge’s hands to react.

Von Kluge's decision to withdraw marked the end of the battle of Mortain and the beginning of a German withdrawal As July 1944 turned to August, Hitler saw an opportunity to

${ }^{57}$ German Seventh Army, "War Diary”, Volume 1, 6 June 1944 to 16 August 1944, Translations, Available at the Ike Skelton Combined Arms Library, N-9821-A, 203; Blumenson, 463 and 473; "VII Corps AAR 1-13 AUG," in Battle Analysis: Cobra Mortain Siegfried, Volume 3, Part 2 (Washington, DC: Government Printing Office, 1944), 99.

${ }^{58}$ Blumenson, 487-488; Reardon, Victory at Mortain, 199 and 231; German Seventh Army, "War Diary”, Volume 5, 12.

59 “VII Corps AAR 1-13 AUG,” 136. 
stop the Allied breakout at Avranches. On August 7, they assembled XLVII Corps and attacked the US 30th Infantry Division at Mortain in an attempt to take advantage of that opportunity. However, Allied tempo all along the Normandy front created pressure, which prevented the Germans from attacking effectively. By August 8, the German attack culminated. ${ }^{60}$ By August 12, the Germans transitioned into full withdraw. ${ }^{61}$ What does Mortain teach about the operational art required when using a medium force to defeat a heavy force?

Analysis: Mortain, Tempo, and Operational Art

Allied tempo all along the Normandy front caused the defeat of Seventh German Army at Mortain. The battle for Mortain illustrates the connection of tempo and mass. Hitler directed an all out offensive toward Avranches, but Seventh German Army massed only massed half the combat power Hitler expected. The Allied tempo created pressure that prevented the Germans from disengaging Panzer Divisions and assembling them for the attack. Air superiority enabled tempo, which kept the pressure on the Seventh German Army and prevented them from massing for Operation Luttich. The inability to mass combat power caused the German attacks to penetrate along a narrow front, which the 30th Infantry Division contained. Allied tempo was critical in the defeat of the Seventh German Army at Mortain.

Hitler intended eight divisions to take part in Luttich, but von Kluge spared only four divisions due to the constant Allied tempo all along the front. Von Kluge's Seventh Army requested five panzer divisions from Panzer Group West, but only received one. Panzer Group West's Commander, Field Marshall Hans Eberbrach, explained that the British-Canadian offensive failed to achieve gains but still threatened his position. He further offered to exchange

${ }^{60}$ L. R. Adair et al., 2-4, 4-11, and 4-17.

${ }^{61}$ L. R. Adair et al., 2-4, 4-11, and 4-17; "VII Corps AAR 1-13 AUG,” 136. 
1st SS Panzer Division for the 89th Infantry Division. Hitler suggested delaying the attack to wait for 9th and 10th SS Division. However, the Allied pressure toward Caen made disengaging these divisions far too risky. ${ }^{62}$ This meant that Hitler's counter attack contained half the combat power initially envisioned because of British-Canadian pressure against Panzer Group West.

The Allied tempo along the front created pressure, which prevented the Germans from achieving mass. For example, the XLVII Panzer Corps reported that the 2nd Panzer Division arrived at its assembly area only an hour before they were set to attack without its attachments of Panthers, assault guns, and mechanized artillery from the 116th Panzer Division. Meanwhile, 84th Infantry Division replaced 116th Panzer Division in a defensive positions near Vire so 116th Panzer could take part in the German attack at Mortain. However, the relentless tempo of the Allied attack created a penetration in the 84th Division sector. LXXXIV Corps had to recommit 116 Panzer to reduce this penetration in 84th Infantry Division defense before it could release them to XLVII Corps. Furthermore, 89th Infantry Division’s slow relief, traffic congestion, and allied fighter-bombers hampered 1st SS Division's move to their assembly area. The 116th Division and 1st SS Division's difficulties caused Operation Luttich’s delay by one day. The front stood only three kilometer East of Avranches when the Germans decided to plan the operation, but it stood at 30 kilometer East of Avranches when the Germans were ready to execute. The American push along the front made it critical for Von Kluge to attack without further delay causing 2nd Panzer Division to attack without receiving the requisite attachments. ${ }^{63}$ The net impact of the allied pressure disrupted the German's ability to mass in preparation for the attack.

${ }^{62}$ Blumenson, 459-462; Reardon, Victory at Mortain, 51 and 61-62; Adair et al., 2-5; John Keegan, Six Armies in Normandy (New York, NY: Penguin Books, 1982), 245.

${ }^{63}$ German Seventh Army, "War Diary”, 4-7; Blumenson, 462; German Seventh Army, "War Diary”, Volume 1, 200; Adair et al., 4-3. 
The German inability to mass the requisite combat power created two narrow penetrations with exposed flanks. The German attack meant to create six mutually supporting penetrations, but only two succeeded. For example, the 2nd Panzer Division intended to create two penetrations, but their attacks failed to execute simultaneously. Their northern penetration attacked on time without the proper attachment. However, the southern column delayed their attack by five hours to ensure that it received a tank company from 1st SS Division. This delay gave the American 117th Infantry Regiment time to occupy Barthelemy with a towed tank destroyer platoon. The tank destroyer platoon caused the Germans to conduct a deliberate attack at Barthelemy, which stalled their movement farther West. ${ }^{64}$ The 1 st SS Panzer penetration at le Mensil-Adelee exposed the division's flanks, because 117th Infantry Regiment halted their attack on the southern flank and 116th Panzer Division gained no traction in their attack on the northern flank. The failure to mass combat power caused very narrow penetrations, which were relatively easy to contain.

As described in section one, 30th Infantry Division received attachments that allowed it to over match the attacking German Divisions and it had the advantage of air superiority. German reports often attribute American success at Mortain to airpower; however, air support was only an element that enabled Allied tempo. Certainly, air superiority and field artillery played a significant role in the American success at Mortain. However, the Germans developed techniques to mitigate Allied aircraft like the use of concentrated anti-aircraft guns to prevent allied pilots from delivering accurate strikes. In fact, studies shortly after the war showed that the Allied bomber reports exaggerated enemy losses. ${ }^{65}$ Although Allied air attack destroyed less than

${ }^{64}$ Adair et al., 4-10 and 4-11; Reardon, Victory at Mortain, 123-126; Blumenson, 463.

${ }^{65}$ Mark J. Reardon, Victory at Mortain, 291 and 295; German Seventh Army, "War Diary”, Volume 2, Evening Report 7 August; German Seventh Army, “War Diary”, Volume 3, 910. 
reported, it slowed the German tempo and prevented them from massing. As a tool, air superiority and firepower set conditions for superior tempo.

\section{Conclusion}

Ultimately, Allied tempo prevented the Germans from massing combat power. The battle for Mortain provides a case to analyze medium versus heavy operations. The Germans were unable to mass combat power for the Mortain offensive. The German inability to mass resulted from the allied pressure, which they created through tempo. The Allied pressure caused the Seventh German Army attack to create only a narrow penetration, which 30th Division contained. Although the Germans blamed Allied air superiority for their defeat, air support and attached combat power enabled a greater tempo for the Allied ground forces. Mortain demonstrates that the medium force must maintain a tempo that prevents the heavy enemy force from massing superior combat power.

\section{Section Three: Argentan-Falaise}

In August 1944, the Allies defeated two German Field Armies in the Argentan-Falaise pocket. The Argentan-Falaise pocket provides another case study to analyze medium versus heavy operations. The methodology for this argument uses John Boyd's Observe Orient Decide Act loop (OODA) and anticipation as criteria to measure tempo and transition. During the battle, the Allies surrounded and destroyed two field armies, but the Americans nearly let the Germans escape. The Allies gained the position of advantage through superior tempo. However, they did not maintain this tempo. Furthermore, the Allies failed to press their advantage, because they did not effectively transition to close the Argentan-Falaise Pocket. The Argentan-Falaise Gap illustrates the importance of tempo and transition during medium versus heavy operations. 
Methodology and Criteria: OODA Loop and Tempo

This analysis uses anticipation as criteria to measure the effectiveness of transitions and John Boyd's Observe Orient Decide Act (OODA) loop as criteria to measure tempo. First, the OODA loop theory explains how tempo creates a position of advantage. Boyd's theory says that people move through a maximum of four steps when confronted with a stimulus. These steps consist of Observe, Orient, Decide, and Act. Boyd explains that the entity that moves through the OODA loop fastest gains an advantage in combat, because their actions overwhelm their opponent's ability to react thereby forcing the opponent to cede the initiative. Frans Osinga expands this concept to the organizational level explaining that an organization that moves through the OODA loop faster than its opponent causes the opponent's system to break down. ${ }^{66}$ The OODA loop theory's focus on speed directly relates to tempo. As described in section two, ADRP 3-0 defines tempo as the "relative speed and rhythm of military operations over time with respect to the enemy." ${ }^{67}$ Further, ADRP 3-0 explains that an appropriate tempo allows an entity to gain or retain the initiative. Boyd explains that an organization should manipulate its movement through the OODA loop in such a way as to render the enemy’s OODA loop ineffective. This gives the organization a position of advantage. ${ }^{68}$ Therefore, the OODA loop theory provides criteria to evaluate the effectiveness of an organizations tempo.

Second, anticipation allows effective phasing or transitions. ADRP 3-0 defines phasing as "a planning and execution tool used to divide an operation in duration or activity." ${ }^{69}$ ADRP 3-0 goes on to explain that transitions mark the change of a phase, which requires anticipating

${ }^{66}$ Frans P. B. Osinga, Science, Strategy, and War: The Strategic Theory of John Boyd (New York, NY: Routledge, 2007), 1, 2, and 7.
${ }^{67}$ ADRP 3-0, 4-7.
${ }^{68}$ Osinga, 1.
${ }^{69}$ Ibid., 4-7 and 4-8. 
condition that necessitates a change in mission, focus, or tempo. ${ }^{70}$ Therefore, the anticipation of conditions creates criteria for measuring effective transitions.

Overview: German Defeat at Argentan-Falaise Gap

The Germans received a severe defeat at Argentan-Falaise, but it could have been much worse. The Argentan-Falaise gap represents a significant clash of the medium weight Allied forces and the heavy weight German force. The Argentan-Falaise salient resulted from the German focus on closing the Cobra breakout at Avranches. Inside the salient, the Allies surrounded two German armies. The III Corps Commander, General Omar Bradley, hesitated to exploit his success moving from LeMans toward Argentan. This hesitation allowed the Germans to hold the pocket open for five days. Bradley’s decision gave the Germans time to strength the shoulders of the pocket at Falaise and Argentan. The Allies eventually closed the pocket further east at the towns of Trun and Chambois. The remnants of the two German armies broke out from the encirclement, allowing all but one Corps headquarters to escape before the allies collapsed the pocket for good. In August 1944, the Allies effectively defeated two German field armies at Argentan-Falaise Pocket, but missed the opportunity to capture several corps headquarters. ${ }^{71}$

The Argentan-Falaise salient formed when elements of Seventh German Army attacked from Mortain toward Avranches in attempt to plug the rupture made by Operation Cobra. As described in section two, Seventh Army's offensive at Mortain failed. The failed offensive left Fifth Panzer Army defending from Cabourg in the north to near Mortain in south. The Seventh German Army controlled a narrow front from Mortain to Raines. The failure to close the rupture created two problems for the Germans. First, the Germans reallocated a Panzer division from the

${ }^{70}$ Osinga, 4-7 and 4-8.

${ }^{71}$ The loss of a staff was significant, because of the experience of the senior members of the staff could not be replaced. 
defense in the north to continue the Mortain offensive. This weakened Fifth Panzer Army defensive position between Caen and Raines. The commander of all Allied Ground Forces, General Bernard Montgomery, recognized the German displacement and ordered the British and Canadian Armies to attack south toward Falaise. ${ }^{72}$ Second, the German's focus toward Avranches allowed Third Army to take Le Mans exposing Seventh German Army's southern flank. The commander of American forces, Bradley ordered Third Army to take advantage of the open southern flank by attacking from LeMans to Argentan. Thus, the Allies created a salient around Seventh German Army and Fifth Panzer Army. The Allies intended to close the salient between Falaise and Argentan, however closing the circle proved to more difficult than expected ${ }^{73}$.

${ }^{72}$ Eberbrach, 42-44; Blumenson, MAP 17; Canadian Participation in the Operations in North-West Europe, 5-6.

${ }^{73}$ George S. Patton, Chapter 3: August Operations, Available at the Ike Skelton Combined Arms Library, N-11480-A-4, 24 and 26; Miller 90; L. F. Ellis et al., Victory in the West: The Battle of Normandy Volume I, ed. James Butler (London, England: Her Majesty's Stationary Office, 1962), 425; Canadian Participation in the Operations in North-West Europe, 5; Blumenson, Map 17 


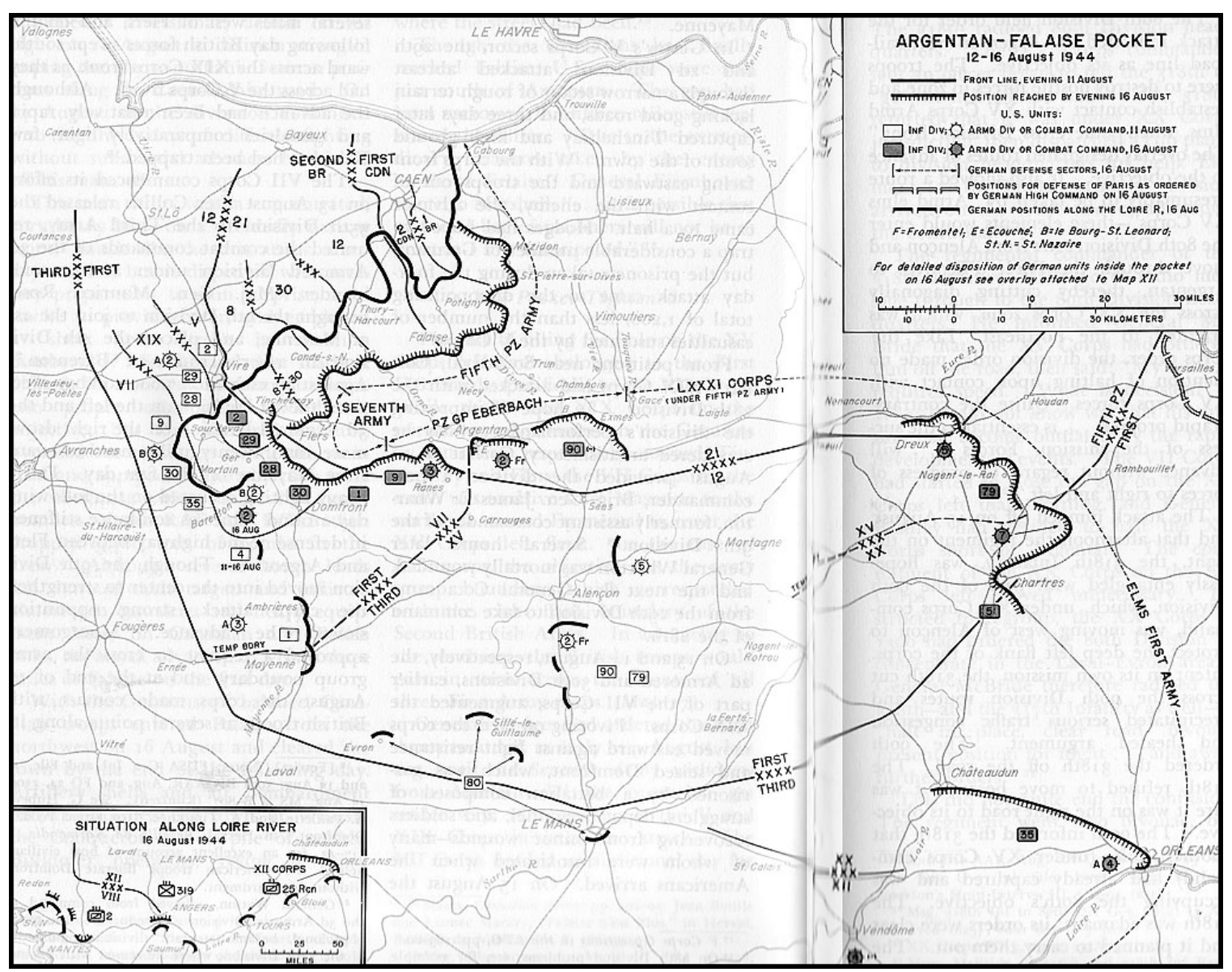

Figure 2. Argentan-Falaise Pocket

Source: Martin Blumenson, U.S. Army in World War II, The Europe Theater of Operations: Breakout and Pursuit (Washington, DC: Government Printing Office, 1961), 513.

On August 12, 1944, Third Army was in position near Argentan, but chose not close the gap. The British and Canadian attack toward Falaise ground southward slowly. The Third Army moved swiftly through two German corps to their position near Argentan. The Allies planned for Third Army in the south to link in with the British and Canadians from the north approximately halfway between Argentan and Falaise, which would close the salient surrounding the Germans. However, the British and Canadian made slow progress toward Falaise. On August 12, Third Army occupied positions at Argentan with no German elements in position to hold the gap from 
the south. However, the German Fifth Panzer Army prevented the British and Canadians from closing the gap from the north. ${ }^{74}$ The contrast between the American and Canadian/British tempo created a dilemma for Bradley. Either Bradley could attacked to close the gap risking over extending Third Army while moving head-on toward the British and Canadians, or he could wait for the British and Canadian to take Falaise at the risk of allowing the Germans to re-enforce the shoulders of the gap. Bradley left the gap open. ${ }^{75}$

Bradley’s decision allowed the German's time to re-enforce the shoulders of the gap holding it open for five more days. ${ }^{76}$ Contrary to American intelligence estimates, the Germans had not yet ordered a withdraw, when Bradley decided against closing the pocket. ${ }^{77}$ On August 11, Hitler approved the newly constituted Army Group Eberbrach with four division to employ against Third Army. The Germans moved two divisions toward Third Army on that night and two more on the next night. By August 13, the Germans moved four divisions into Third Army’s way preventing the Allies from closing the gap between Argentan and Falaise. This caused the allies to close the gap further west at Trun and Chambois. On August 19, the 1st Polish Division, under operational control of the Canadians, closed the Argentan-Falaise Pocket by linking with the Americans at Chambois. The German were not defeated yet. ${ }^{78}$

On August 20 and 21, the German remnants broke out from the Argentan-Falaise pocket. By August 19, only the remnants of four corps remained in the pocket. The III Parachute Corps in the north and the XLVII Panzer Corps in south led the breakout. The 116th Panzer Division held

${ }^{74}$ Patton, 27; Blumenson, Map XI and 509-510; Gersdorff, 57-58.

${ }^{75}$ Ellis, 428 -429; D’Este, 430; Miller, 110-112.

${ }^{76}$ Gersdorff, N17500.55-D.2, 63; Miller, 95-97.

${ }^{77}$ Dieter Ose, Entscheidung im Westen 1944 (Stuttgart, Germany: Deutsche VerlagsAnstalt, 1985), 236. Translated from German by Oberstleutnant i.G. Kim Frerichs; Ellis, 429.

${ }^{78}$ German Seventh Army, "War Diary”, Volume 1, 206; Ose, 236; Gersdorff, 63; Canadian Participation in the Operations in North-West Europe, 88; Ellis, 429; Blumenson, Map XI, 525, and 527. 
the southern flank, LXXXIV Corps held the northern flank, and LXXIV maintained rear guard. After the III Parachute Corps and XLVII Corps crossed the Dive River to safety, what little remained of LXXXIV Corps and LXXIV Corps withdrew in disorder. On August 21, the pocket closed for the last time, and the surrounded Germans surrendered. Historians disagree on the exact loss suffered by the Seventh German Army and Fifth Panzer Army during this battle, but the best estimates put these two Armies under twenty five percent strength. However, the German catastrophe included several notable successes. For example, the Germans lost only one Corps headquarters and the 116th Panzer Division, yet retained better than sixty percent of its combat power. ${ }^{79}$

The German's defeat at Argentan-Falaise represented a significant blow, but the German's might have been in a much worse situation. The German attack to reestablish the defensive line from Mortain to Avranches gave the allies the opportunity to create the ArgentanFalaise pocket. On August 13, the Americans were in position to close the pocket, but failed to do so. Five days later, the allies finally closed the pocket. On August 20-21, the remnants of the surrounded German units broke out to the west and the allies closed the pocket for the last time. Although remnants escaped, the Allies defeated two full German Armies in the Argentan-Falaise pocket.

Analysis: Argentan-Falaise, Tempo, and Operational Art

A combination of enemy action and allied decisions slowed the American tempo giving the Germans a second chance. The Argentan-Falaise Pocket illustrates the critical nature of tempo in medium versus heavy operations. The allies' swift tempo caused the Argentan-Falaise salient

${ }^{79}$ D'este, 432; Ellis, 176 and 447-448; Miller, 176-177 and 448; Blumenson, 547-558 and MAP XI; Gerhard Mueller, Report of the commitment of the 116 Armor Division from 11-24 Aug 44. Translation, Available at the Ike Skelton Combined Arms Library, N-17500.263, 22 and 24; Canadian Participation in the Operations in North-West Europe, 101. 
to form. However, Bradley's decision to slow the tempo gave the Germans a chance to withdraw. The Allies' tempo created the Argentan-Falaise Salient, but the Americans slowed their tempo before closing the pocket. This prevented the Allies from delivering an even more devastating blow.

The Allies’ tempo all along the front prevented the Germans ability to mass at Mortain, as described in section two, and denied the Germans the freedom of manuver to stop the Argentan-Falaise salient from forming. The rupture caused by Cobra created a dilemma for the Germans. On one hand, the Germans wanted to close the rupture at Avranches, but need to commit Panzer Divisions to the attack. On other hand, the Germans needed panzers to hold the line running from Vire to Caen. Strengthening the attack toward Avranches weakened the defense between Vire and Caen. ${ }^{80}$ Furthermore, the American tempo all along the front interrupted the Germans’ OODA Loop and prevented German Army from committing requisite combat power to either the offense or the defense. The Germans observed the Cobra breakthrough, oriented on it, and decided to close it, but could not act without compromising either the eastern defense or the western attack. ${ }^{81}$

The American decision to slow to a deliberate tempo allowed the Germans to re-enforce the shoulder of the pocket at Argentan. The Third Army maintained a fast pace approaching Argentan. The Seventh German Army remained focused on the Mortain attack at the Hitler's behest. Bradley's decision to stop at Argentan gave the Seventh German Army the opportunity to convince Hitler to move units into position confronting the American attack from the south. ${ }^{82}$ In

${ }^{80}$ D'Este, 414; Eberbrach 41; Reardon, 92.

${ }^{81}$ Osinga, 2.

${ }^{82}$ Patton, 27; Miller, 95-96, 107, and 110; Germany Seventh Army, Volume 1, 204; Eberbrach, 44; Gersdroff, 57-58 and 63. 
Boyd's terms, the German observed the American attack from the south, oriented on it, but needed time to make the decision before they could act. ${ }^{83}$ Bradley's order to hold gave Hitler the time he needed to complete the OODA loop and order units to move to the Argentan-Falaise gap in time to oppose the Americans. ${ }^{84}$ Ultimately, the American operated on a faster OODA loop then German until Bradley's decision to stop at Argentan, which gave the Germans a temporary advantage.

The Americans missed an opportunity to create a crushing blow against the German army at Argentan. The ensuing actions illustrate the effect of tempo when medium forces operate against a heavy force. The Allies outpaced the Germans creating the Argentan-Falaise Pocket. The Germans were able delay closing the pocket for five days, because of III Corps pause at Argentan. The failure to close the pocket early prevented the Americans from creating a more destructive attack against the Germans.

Analysis: Argentan-Falaise, Transitions, and Operational Art

The Allied attack grabbed the neck of two German field armies, but then they loosened their grip before driving home the decisive blow. The actions around the Argentan-Falaise gap in August 1944 illustrate the importance of phasing and transition for a medium force. The Allies lacked a detailed plan to close the encircled German Armies. Therefore, the Americans failure to anticipate the condition needed to close the gap, which allowed the Germans the opportunity to reinforce the opening of the gap. Furthermore, the American hesitation gave the Germans room to assemble for a breakout. The Allies allowed Seventh Germany Army and Fifth Panzer Army to

\footnotetext{
${ }^{83}$ Osinga, 2.

${ }^{84}$ Ellis, 428-429;D’Este, 430; Miller,110-112.
} 
attempt a break out of the encirclement, because they inadequately transitioned to close the Argentan-Falaise Pocket.

The Allies lacked a detailed plan to close the gap. Seeing the opportunity created by the American seizure of LeMans, Montgomery approved Bradley’s orders for Third Army to attack toward Argentan, while British and Canadians attacked toward Falaise. ${ }^{85}$ This meant two allied field armies were attacking directly at each other. The opposing position of the two armies created a dangerous and complicated situation, which Bradley acknowledged ${ }^{86}$ However, neither Bradley nor Montgomery's actions indicate that they created a plan to transition to a gap closing. Three facts support this conclusion. First, Bradley made it clear that he never recommended to Montgomery that Third Army close the gap, which indicates that the Allies failed to complete a detailed plan to close the German encirclement. Second, Montgomery altered the direction of the Canadian and British attack away from Falaise without contacting Bradley indicating that Montgomery failed to anticipate the implication of this turn. ${ }^{87}$ Third, Bradley judged that Third Army lacked the combat power to close gap, because intelligence indicated the German's retreat out of the pocket had begun. However, the German's withdraw had not been ordered. ${ }^{88}$ The incongruity between the American intelligence estimate and the reality of the German situation indicates that the American's reconnaissance effort did not anticipate identifying the conditions required to encircle the Germans.

${ }^{85}$ Ellis, 425.

${ }^{86}$ Omar Bradley, A Soldier Story (New York , NY: Henry Holt and Company, 1951), 377; Bernard L. Montgomery, The Memoir of Field Marshall the Viscount Montgomery of Alamein (London, England: Collins Clear-Type Press, 1958), 260-264; In his Memoir, Montgomery addresses his concern with Eisenhower Leadership during this period of time. His Memoir made no mention of Bradley's decision to leave the Argentan-Falaise Gap open. This indicates that Montgomery failed to attachment significant importance to the event, but certainly, he understood the danger of two armies attacking toward each other.

${ }^{87}$ Bradley, 377.

${ }^{88}$ Gersdroff, 64. 
The Allies' failure to anticipate the condition required to close the gap gave Panzer Group Eberbach time to reinforce the shoulders of the gap. On August 11, Seventh German Army received permission from German high command to move forces south against Third Army. The Seventh German Army planned to move four division under Panzer Group Eberbach against Third Army, but the move required two nights to execute due to allied fighter-bomber activity. On August 12, Bradley found himself in position to close the gap with no German resistance, but he hesitated due the risk the situation presented. Meanwhile, two German division moved to stop him, but needed time to establish a solid defensive position. By August 13, when Bradley resumed the attack, four division stood between Third Army and the Argentan-Falaise gap. Bradley decided to wait, which allowed the Germans to re-enforce the Argentan shoulder and hold the gap open until August 19. ${ }^{89}$ The American twenty-four hour delay allowed four German divisions to organize and prepare to defend against encirclement. Ironically, the Germans became proficient at escaping enciriclements from their fighting the Russians on the Eastern Front. $^{90}$

The British and Canadian attack in the north moved slowly and the Americans in the south stopped all together giving the Germans the space required to conduct a breakout once the pocket closed. By August 14, the Germans bolstered the defense at Falaise and Argentan, which meant the converging Allied Armies needed to meet farther west at Chambois. However, this movement gave the German's ten kilometer more ground to assemble and prepare to breakout. Figure 3 illustrates the gap created by the Allied shift west. The dashed line indicates the planned closing location between Falaise and Argentan. The solid line indicates the actual locations where

${ }^{89}$ Gersdroff, 63-64; Ose, 236; Bradley, 377; Miller, 107-108; Blumenson, 549-550.

${ }^{90}$ Department of the Army Pamphlet No. 20-234, A Historical Study Operations of Encirclement: German Experience in Russia (Washington, DC: Government Printing Press, 1952), 52-66. 
the Allies closed the pocket between Trun and Chambois. Four German corps assembles for the breakout in the area created by the allied decision to close the gap at Chambios indicated by the blue oval on figure $3 .{ }^{91}$ In other words, the failure to anticipate the conditions required to close the gap caused the decision to close the pocket further east. Closing the pocket to the east loosened the noose around the German Armies enough to allow them to assemble for a breakout

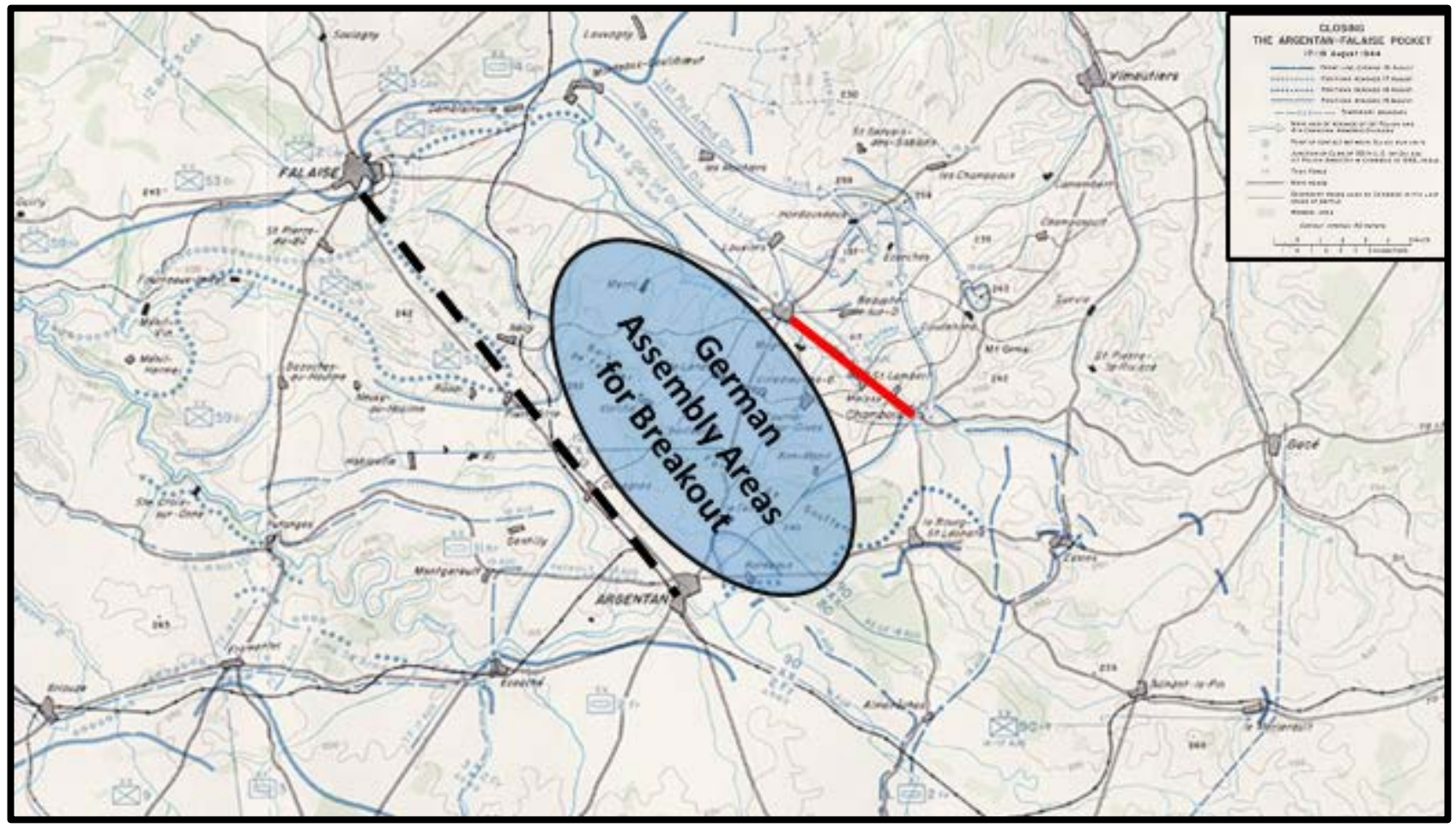

attempt.

Figure 3. German Assembly Areas for the Argentan-Falaise Breakout

Source: Martin Blumenson, U.S. Army in World War II, The Europe Theater of Operations: Breakout and Pursuit (Washington, DC: Government Printing Office, 1961), Map XI and Overlay Map XI.

${ }^{91}$ Bradley, 371; Patton, 29; Blumenson, Overlay Map XI. 
Although the encirclement of German Fifth Panzer and Seventh Army by the Allies created a defeat for the German Army, the Allies missed the opportunity to deliver a more crushing blow. The Americans' lack of anticipation at Argentan exhibits the particular importance of phasing and transition in medium verses heavy operations. The combined American and British command recognized the risk of closing the gap, but missed anticipating the detailed requirements to transition to the complicated task of closing the gap. Without a detailed plan, the Americans put little planning effort into anticipating and setting the conditions required to close the gap. ${ }^{92}$ This required the Allies to delay operations for 24 hours. The German took advantage of delay by using the time to re-enforce the shoulders of the Argentan-Falaise gap. This ultimately created the space that the Germans required to assemble for the break out. The Allies ineffective transition to close the Argentan-Falaise gap prevented the Allies from dealing a more crippling blow to the German Army.

\section{Conclusion}

Allied tempo, phasing, and transition played key roles in the encirclement of two German Armies near Falaise and Argentan in August 1944. Allied operations during this time provide insight for operational level practitioner to plan for medium versus heavy operations. Boyd's OODA loop and anticipation are criteria to measure tempo and transitions. As the result of the German's failed offensive at Mortain, the Allies surrounded two German field armies. However, the Americans reduced their tempo and lacked an effective transition, which allowed the Germans to conduct a breakout of the encirclement. The Allies gained the advantage through high tempo operations as they took Lemans and moved toward Argentan. The Germans were incapable of

${ }^{92}$ None of the sources used in this monograph gave any clear indication why the Allies did not focus a planning effort toward closing the gap. The reason for this oversight may lay in the command structure of the Allies. For more information on the command structure of the Allies see Bradley's, Ellis', or Blumenson's books referenced in the bibliography. 
matching these moves. However, the Americans slowed their tempo at Argentan. The Americans changed their tempo partly because of poor anticipation of the transition required to encircle the Germans. The Germans used this pause to set the conditions to conduct a breakout. The Argentan-Falaise episode illustrates the critical nature of tempo, phasing, and transition in medium verses heavy operations.

\section{Conclusion}

The historical study of medium versus heavy operations remains relevant in the modern army. Medium versus heavy denotes the use of medium armor to engage heavy armor. This subject remains relevant because of the US Army’s focus on a rapid deployability. The Army’s focus on this type of force reflects in the increasing number of medium units. Current budget constraint makes the medium force a more acceptable alternative in comparison to its heavy counterparts. ${ }^{93}$ Although the US Army would like to avoid pitting a medium force against a heavy force, the terrain and enemy may preclude this possibility. Section two demonstrated by showing the inadequacy of of doctrine in World War II for the employment of tank destroys.

The relevance of medium versus heavy operation compels a question:What elements of operational art are most critical to medium force when fighting a heavy force? This discussion answered this question from a planning perspective. It seeks to inform planners on how best to plan in a medium versus heavy situation. The study of the employment of medium forces in insurgency and guerilla war remains outside the scope of this discussion. For the traditional definitions of war, army versus army, in mind, tempo, phasing, and transitions are most critical in medium versus heavy operations.

${ }^{93}$ Army Posture Statement 2014, 2 and 16; QDR 2014, 12; Reardon and Charleston, 5-6; Vick et al., 19; Stanley, Atwell, and McGee, Appendix D. 
Before drawing conclusion about the nature of medium versus heavy operations, section one sets the context of these type of operations. In order to discuss the use of medium forces, one must first define a medium force's character. The term medium implies a force that lies between to other forces. This relational definition becomes problematic, because an organization may be medium in one context and heavy in another. The definition of medium this argument uses draws from the functional purpose of the medium force. A medium force is any force which reduces it capabilities to increase its operational or strategic reach. World War II represents an opportunity to study these types of operations, because the American armor division maintains the characteristics of a medium force and the German Panzer Division is characteristic of a heavy force. Finally, the evolution of the World War II tank destroyer doctrine teaches that the enemy and terrain can nullify doctrine in dictating how a unit will fight. This means that the idea that the US Army would simply avoid fighting a heavy force with a medium force would be ideal, but terrain and the enemy may make it unavoidable.

Next, sections two and three examine the German offensive at Mortain and the following encirclement of the Germans at Argentan-Falaise. These two events provide cases to examine medium versus heavy operations. After the American breakout from the bocage, the Germans attempted a counter attack from east to west near Mortain. The failure of this counterattack gave the allies the opportunity to encircle two German field armies. ${ }^{94}$ The American Army parried the German counter attack because the tempo of Allied operations denied the Germans the ability to mass the requisite combat power to mount an adequate offensive. Further, the rapid tempo of Allied operations pushing east created a deep salient around two German field armies. However, the American slowed their tempo near Argentan. The Americans were concerned about the risk created by attempting to surround German units while linking in with the Allied units across the

\footnotetext{
${ }^{94}$ Adair et al. 2-1 and 2-13; Eberbrach, 44; Blumenson, Map 17.
} 
gap. The American reduction in tempo was caused by the failure to transition quickly to close the gap. This gave the Germans time to reinforce the opening of the gap. The allies eventually crushed the two German armies, but the reduction in tempo delayed their encirclement by five days and allowed the German the space necessary to conduct a breakout. ${ }^{95}$ These two major events illustrate how transitions, phasing, and tempo contribute to medium versus heavy operations.

Recommendations

The lesson derived from World War II sum up in two words: tempo and transitions. These two concepts provide the basis of the recommendations to future planners. The case studies of American forces in World War II emphasize the importance of tempo in medium versus heavy operations. The planner's approach requires that ability to mitigate risk without slowing tempo. The planner can focus limited combat power in support of the medium force to mitigate risk. During medium versus heavy operations, the medium forces must maintain a rapid tempo by using phasing to focus combat power.

American success using a medium force in World War II illustrates the importance of tempo. Tempo denies the enemy the ability to mass combat power at the place of his choosing. The German offensive at Mortain illustrates this effect. The Germans struggled to realign their division to make an effective attack against the Americans. Further, the American reduction in tempo near Argentan shows how failure to maintain a rapid tempo gave the German a temporary advantage.

The medium forces planner must resist the tendency to reduce tempo to mitigate risk. Rapid tempo incurs risk of its own. This risks stems from the tempo creating a situation where the medium forces combat power fails to be in the correct position to counter the heavy forces greater

${ }^{95}$ Patton, 27; Bradley, 377; Gersdoroff, 17500-D.2, 63; Blumenson, Map XI. 
combat power. The American Commander at Argentan, Bradley, indicated that he slowed the American tempo specifically to mitigate risk as his army approached the combined Canadian and British Army across the gap. ${ }^{96}$ However, in medium versus heavy operations the planner must focus on the mitigation of risk by other means then slowing the tempo.

In order to enable rapid tempo, the planner must phase operations in a way that concentrates firepower during periods where the medium force faces increased risk. Section one illustration of aggregated caliber shows how the VII Corp augmented the 30th Infantry Division with firepower to mitigate risk. The ideal solution to the decreased combat power of the medium forces is to augment it with other types of firepower like artillery and close air support. However, these assets are finite. In World War II, the Allies were able to mass more firepower then the Germans, but in the future, this may not be possible. Therefore, the planner must identify those points of high risk. Based on those points, the planner should then design phases so that the firepower transitions to support the medium force. In other words, the focus of the transition enables the firepower to support the tempo of the medium force.

The asymmetry of medium versus heavy operations creates a problem for the medium force. The problem is relevant, because the strategic direction of the United States encourages the growth of medium forces. This means the study of the medium versus heavy operations becomes a concern should a significant war occur. The Allied experience in France during World War II provides excellent context for this study. The American success defending at Mortain and encircling the Germans at Argentan-Falaise illustrates the importance of tempo, transitions, and phasing. Taken together, the most critical elements of operational art are tempo, transitions, and phasing during medium versus heavy operations.

${ }^{96}$ Bradley, 377. 


\section{Bibliography}

Adair L. R., W. H. Spears, R. Ivany, M. Q. Barbour, D. E. Taylor, and F. E. Galati. "Mortain: Defensive, Deliberate Defense, 30th Infantry, 9-13 August 1944." Fort Leavenworth, KS: Combat Studies Institute, 1983.

Blumenson, Martin. United States Army in World War II The European Theater of Operation: Break Out and Pursuit. Washington D.C.: US Government Printing Office, 1961.

Bowman, Stephen L., John M. Kendall, and James L. Saunders. Motorized Experience of the 9th Infantry Division: Fort Lewis, WA 1980-1989. Fort Lewis, WA: Headquarters 9th Infantry Division, 1989.

Bradley, Omar N. A Soldier's Story. New York, NY: Henry Holt and Company Inc, 1951.

Brown, John S. Draftee Division: The $88^{\text {th }}$ Infantry Division in World War II. Lexington, KY: The University Press of Kentucky, 1986.

Combat Studies Institute. Sixty Years of Reorganizing for Combat: A Historical Trend Analysis. Combat Studies Institute Report 14. Fort Leavenworth, KS: Combat Studies Institute, 1990.

Cameron, Robert S. Mobility, Shock, and Firepower: The Emergence of the U.S. Army's Armor Branch, 1917-1945. Washington, DC: Center for Military History, 2008.

Congressional Budget Office. Congressional Budget Office Study: An Analysis of the Army's Transformation Programs and Possible Alternatives. Washington, DC: Congressional Budget Office, 2009.

Department of Defense. A Statement of the Posture on the Posture of the United States Army 2014. Washington, DC: Department of Defense, 2014.

Department of the Army. Quadrennial Defense Review 2014. Washington, DC: Department of Defense, 2014.

Department of the Army Pamphlet (DA PAM) NO. 20-234, Historical Study Operations of Encircled Forces: German Experience in Russia. Washington, DC: Government Printing Press, 1952.

D'este, Carlo. Decision in Normandy. New York, NY: Dutton,1983.

Directorate of History. Canadian Participation in the Operations in North-West Europe, 1944. Report 65. Part III. Ottawa, Canada: Directorate of History, 1953.

Eberbrach, Hienrich. Report on the Fighting of Panzergruppe West (Fifth Pz Army) from July 39August 1944. Translations, Available at the Ike Skelton Combined Arms Library, MS \#B-840.

Ellis, L. F. et al. Warhurst, and James Robb. Victory in the West: The Battle of Normandy Volume I. Edited by James Butler. London, England: Her Majesty's Stationary Office, 1962.

Ford, Pat, Edwin Burba, and Richard Christ. Review of Division Structure Initiatives. Alexandria, VA: Human Resources Research Organization, 1994. 
Forty, George. German Tanks of World War Two 'In Action'. New York, NY : Sterling Publishing Co, 1987.

Foss, Christopher F., eds. Jane’s: Armour and Artillery 2004-2005. Alexandria, VA: Jane’s Information Group, 2004.

Fubini, Eugene G. Task Force on the Application of High Technology Ground Force Operations: An Assessment of the United States Army's High Technology Test Bed (Made during the Period July 1981--- May 1982). Washington, DC: Office of the Secretary of Defense Research and Engineering, 1983.

German Seventh Army, “War Diary”, Volume 1, 16 July 1944 to 16 August 1944, Translation, Available at the Ike Skelton Combined Arms Library, N-9821-A.

, “War Diary”, Volume 2, 16 July 1944 to 16 August 1944, Translation, Available at the Ike Skelton Combined Arms Library, N-9821-B.

, "War Diary”, Volume 3, 16 July 1944 to 16 August 1944, Translation, Available at the Ike Skelton Combined Arms Library, N-9821-C.

"War Diary”, Volume 4, 4 August 1944-13 August 1944, Translation, Available at the Ike Skelton Combined Arms Library, N-9821-E.

Gersdroff, Rudolf. The Campaign in North France, Volume IV Chapter 4. Translations by C. L'Lorsa, Available at the Ike Skelton Combined Arms Library, N-17500.55-D.2.

Halle, Armin. Tanks: An Illustrated History of Fighting Vehicles. Greenwich. CT: New York Graphic Society, 1971.

Horowitz, Stanley A., Robert J. Atwell, and Shaun K.McGee. Analyzing the Cost of Army Alternative Active/Reserve Forces Mixes. Alexandria, VA: Institute of Defense analysis, 2012.

Hunnicutt, R. P. Sherman: A History of the American Medium Tank. Novato, CA: Presidio Press, 1978.

Jackson, Paul et al., eds., Jane's: All the World's Aircraft 2010-2011. Alexandria, VA: Jane’s Information Group, 2010.

Johnson, David E. Adam Grissom, and Olga Oliker. In the Middle of the Fight: An Assessment of Medium-Armored Forces in Past Military Operations. Santa Monica, CA: Rand Corporation, 2008.

Johnson, Stuart E. et al. A Review of the Army's Modular Force Structure. Santa Monica, CA: Rand Corporation, 2011.

Keegan, John. Six Armies in Normandy. New York, NY: Penguin Group, 1982.

MacDonald, Charles. Company Commander. New York, NY: Bantam, 1947.

Mazarr, Michael J. Light Forces \& the Future of U.S. Military Strategy. New York, NY: Brassey’s Inc., 1990.

Miller, Robert A. August 1944. Navato, CA: Presidio, 1988.

Montgomery, Viscount. The Memoirs of Field-Marshall the Viscount Montgomery of Alamein, K.G. London, England: Collins Clear-Type Press, 1958.

Mueller, Gerhard. Report of the Commitment of the 116 Armored Division from 11-24 Aug 44. Translation. Available at the Ike Skelton Combined Arms Library, N-17500.263. 
Ose, Dieter. Entscheidung im Westen 1944. Stuttgart, Germany: Deutsche Verlags-Anstalt, 1985.

Osinga, Frans P. B. Science, Strategy and War: The Strategic Theory of John Boyd. New York, NY: Routledge, 2007.

Oxford English Dictionary. New York, NY: Oxford University Press, 1980.

Patton, George S. Chapter 3: August Operations. Available at the Ike Skelton Combined Arms Library, N-11480-A-4.

Reardon, Mark J. Victory at Mortain: Stopping Hitler's Panzer Counter Offensive. Lawrence, KS: University Press of Kansas, 2002.

Reardon, Mark J. and Jeffery A. Charleston. From Transformation to Combat: the First Stryker Brigade at War. Washington, DC: Center of Military History, 2007.

Rush, Robert S. Hell in the Hürtgen Forest: The Ordeal and Triumph of an American Infantry Regiment. Lawrence, KS: University Press of Kansas, 2001.

Student Text 4-1, Theater Sustainment Battle Book. Fort Leavenworth, KS: Command and General Staff College, 2014.

Table of Organization and Equipment No. 7. Infantry Division: 1944. Washington, DC: War Department, 1944.

Table of Organization and Equipment No. 17. Armor Division: 1942. Washington, DC: War Department, 1942.

Table of Organization and Equipment No. 17. Armor Division: 1944. Washington, DC: War Department, 1944.

Technical Manual (TM-E) 30-451. Handbook on German Military Forces. Washington, DC: Government Printing Press, 1945.

U.S. 30th Infantry Division G2, “After Action Report August 1st -31st 1944,” Available at the Ike Skelton Combined Arms Library, N12139.

U.S. Army Doctrine Publication (ADP) 3-0, Unified Land Operations. Washington, DC: Government printing Office, 2011.

U.S. Army Doctrine Reference Publication (ADRP) 3-0, Unified Land Operations. Washington, DC: Government printing Office, 2012.

U.S. Field Manuel (FM) 18-15, Tank Destroyer. Washington, DC: Government Printing Press, 1942.

U.S. Government Printing Press. Battle Analysis: Cobra, Mortain, Siegfried, Vol 3 Part 2. Washington, DC: Government Printing Office, 1944.

U.S. Joint Publication (JP) 3-0, Joint Operations. Washington, DC: Government Printing Office, 2011.

Vick, Alan et al., The Stryker Brigade Combat Team: Rethinking Strategic Responsiveness and Assessing Deployment Options. Santa Monica, CA: Rand Corporation, 2002.

Zaloga, Steven J. US Tanks and Tank Destroyer Battalions in the ETO 1944-45, edited by Duncan Anderson, Marcus Cowper, and Nikolai Bogdanovic. Oxford, UK: Osprey Direct, 2005. 